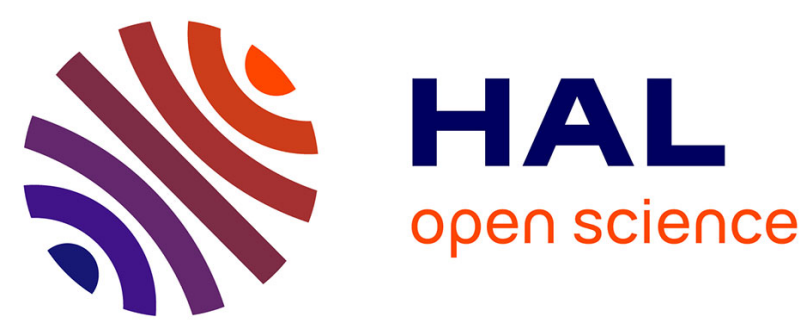

\title{
The Fuegian thrust-fold belt: From arc-continent collision to thrust-related deformation in the southernmost Andes
}

Torres Carbonell, Sebastián J Cao, Mauricio González Guillot, Victoria

Mosqueira González, Luis V. Dimieri, Florian Duval, Stéphane Scaillet

\section{To cite this version:}

Torres Carbonell, Sebastián J Cao, Mauricio González Guillot, Victoria Mosqueira González, Luis V. Dimieri, et al.. The Fuegian thrust-fold belt: From arc-continent collision to thrust-related deformation in the southernmost Andes. Journal of South American Earth Sciences, 2020, 102, 102678 (22 p.). 10.1016/j.jsames.2020.102678 . insu-02867714

\section{HAL Id: insu-02867714 https://hal-insu.archives-ouvertes.fr/insu-02867714}

Submitted on 15 Jun 2020

HAL is a multi-disciplinary open access archive for the deposit and dissemination of scientific research documents, whether they are published or not. The documents may come from teaching and research institutions in France or abroad, or from public or private research centers.
L'archive ouverte pluridisciplinaire HAL, est destinée au dépôt et à la diffusion de documents scientifiques de niveau recherche, publiés ou non, émanant des établissements d'enseignement et de recherche français ou étrangers, des laboratoires publics ou privés. 


\section{Journal Pre-proof}

The Fuegian thrust-fold belt: From arc-continent collision to thrust-related deformation in the southernmost Andes

Pablo J. Torres Carbonell, Sebastián J. Cao, Mauricio González Guillot, Victoria Mosqueira González, Luis V. Dimieri, Florian Duval, Stéphane Scaillet

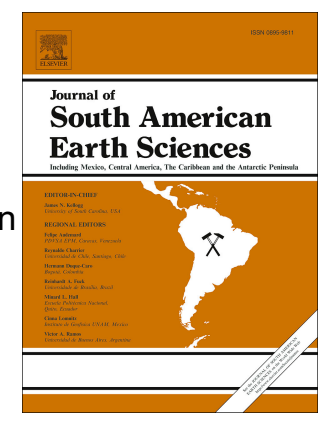

PII: S0895-9811(20)30221-2

DOI: https://doi.org/10.1016/j.jsames.2020.102678

Reference: $\quad$ SAMES 102678

To appear in: Journal of South American Earth Sciences

Received Date: 26 December 2019

Revised Date: 24 April 2020

Accepted Date: 29 May 2020

Please cite this article as: Torres Carbonell, P.J., Cao, Sebastiá.J., Guillot, Mauricio.Gonzá., González, V.M., Dimieri, L.V., Duval, F., Scaillet, Sté., The Fuegian thrust-fold belt: From arc-continent collision to thrust-related deformation in the southernmost Andes, Journal of South American Earth Sciences (2020), doi: https://doi.org/10.1016/j.jsames.2020.102678.

This is a PDF file of an article that has undergone enhancements after acceptance, such as the addition of a cover page and metadata, and formatting for readability, but it is not yet the definitive version of record. This version will undergo additional copyediting, typesetting and review before it is published in its final form, but we are providing this version to give early visibility of the article. Please note that, during the production process, errors may be discovered which could affect the content, and all legal disclaimers that apply to the journal pertain.

(C) 2020 Elsevier Ltd. All rights reserved. 
1 The Fuegian thrust-fold belt: from arc-continent collision to thrust-related

\section{2 deformation in the southernmost Andes}

3 Pablo J. TORRES CARBONELL ${ }^{a}$, Sebastián J. CAO ${ }^{\mathrm{a}, \mathrm{b}}$, Mauricio GONZÁLEZ GUILLOT ${ }^{\mathrm{a}, \mathrm{b}}$,

4 Victoria MOSQUEIRA GONZÁLEZ ${ }^{a}$, Luis V. DIMIERI ${ }^{c}$, Florian DUVAL ${ }^{d}$, Stéphane

5 SCAILLET ${ }^{d}$

$6{ }^{a}$ Centro Austral de Investigaciones Científicas (CADIC-CONICET), Bernardo Houssay

7 200, 9410 Ushuaia, Argentina. torrescarbonell@cadic-conicet.gob.ar, sebacao@cadic-

8 conicet.gob.ar,g_guillot@cadic-conicet.gob.ar, mosqueiravictoria@cadic-

9 conicet.gob.ar

$10{ }^{b}$ Instituto de Ciencias Polares, Recursos Naturales y Ambiente, Universidad Nacional de

11 Tierra del Fuego, Walanika 250, 9410 Ushuaia, Tierra del Fuego, Argentina

12 'Instituto Geológico del Sur (INGEOSUR-CONICET), Departamento de Geología,

13 Universidad Nacional del Sur, Av. Alem 1253, Cuerpo B', 2o piso, 8000 Bahía Blanca,

14 Buenos Aires, Argentina, Idimieri@uns.edu.ar

dInstitut des Sciences de la Terre d'Orléans (ISTO), INSU-CNRS, Université d'Orléans, 1A

rue de la Férolerie, 45071 Orléans Cedex 2, France, florian.duval@cnrs-orleans.fr,

17 sscaille@cnrs-orleans.fr

Corresponding author address and phone number: Centro Austral de Investigaciones

Científicas (CADIC-CONICET), Bernardo Houssay 200, 9410 Ushuaia, Tierra del Fuego, 


\section{Abstract}

26

27

New detailed structural data from the Fuegian Andes including new ages and crosscutting relationships with intrusive rocks, as well as an appraisal of published structural data, support that this orogen evolved as a basement-involved thrust-fold belt after initial formation in an arc-continent collision scenario. New structural data from a deformed $84 \mathrm{Ma}$ intrusive indicate that structures from the collisional event in the Argentine Fuegian Andes are of Campanian age, comprising only the youngest and less intense deformation of the orogenic wedge. In the internal thrust-fold belt, these structures are cut by intrusives with new ages of $74 \mathrm{Ma}$ ( $\mathrm{Ar} / \mathrm{Ar}$ on hornblende). The superposition of thrusts on these early structures indicates a subsequent event in which a thrust-fold belt formed since the Maastrichtian-Danian. Additional new data confirm brittle-ductile thrusting in the central belt, with thrusts joining a common upper detachment in the base of the Lower Cretaceous rocks. These thrusts formed a first-order duplex system that transferred the shortening accommodated in the foreland until the Miocene.

Keywords: arc-continent collision, thrust-fold belt, $\mathrm{Ar} / \mathrm{Ar}$ dating, deformation chronology, Fuegian Andes 


\section{Introduction}

In the last 10 years a systematic research has been carried out in the Fuegian Andes attempting to unveil the structural relationships between a poorly known central belt (between Lago Fagnano and Canal Beagle, Fig. 1a), and the foreland thrust-fold belt located northwards. The connection between both domains was obscured not only by limited structural knowledge of the central belt, but also because the geometry of the foreland structures was only constrained by studies at its external portion, especially at the best exposed Atlantic coast (Álvarez-Marrón et al., 1993; Ghiglione, 2002;

Ghiglione et al., 2010; Torres Carbonell et al., 2011, 2013a; Zanella et al., 2014). In addition, the internal part of the thrust-fold belt (Fig. 1a), involving mostly Cretaceous mudstones and slates with scarce stratigraphic control, was practically not addressed from a structural geology perspective, with the exception of a limited area in Chile (Klepeis, 1994; Rojas and Mpodozis, 2006).

Despite a greater amount of structural data from early works in the central belt of the Fuegian Andes, especially from Cordillera Darwin and surrounding areas (Fig. 1a), our analysis of that research shows us that the deformation of the foreland has been implicitly circumvented. Indeed, early investigations focused their attention on the spectacular deformation of high-grade metamorphic rocks exposed in Cordillera Darwin. These studies, as well as others along the central belt up to Isla de los Estados (Fig. 1a), determined that most of the shortening registered in the Fuegian Andes was of "mid" Cretaceous age (the "main phase" of early works), related to multiple folding and faulting generations and associated regional metamorphism (Bruhn, 1979; Dalziel and Palmer, 1979; Nelson et al., 1980; Cunningham, 1994, 1995; Kohn et al., 1995). An interesting aspect of these studies is that they led to a distinction of the structure of 
the Fuegian Andes with respect to the rest of the Andean Cordillera. Accordingly, the

style of deformation was found to be more similar to the Alpine chain (Nelson et al., 1980), and it was clear that a collisional process closing a prior back-arc basin was responsible for this structural style, in contrast with the geodynamic context of the rest of the Andes of South America (Dalziel et al., 1974; Dalziel, 1986).

Following, and building on this early research, more recent works revealed that after the "main phase" of deformation, thrust-related uplift of the central belt progressed during the Late Cretaceous and the Paleogene (Klepeis, 1994; Kohn et al., 1995; Gombosi et al., 2009; Klepeis et al., 2010; Maloney et al., 2011). It was recognized that at least part of the exhumation in Cordillera Darwin and its surroundings was coeval with thrusting in the foreland (e.g. Bruhn, 1979; Dalziel and Palmer, 1979; Álvarez-Marrón et al., 1993; Barbeau et al., 2009a; Gombosi et al., 2009). However, an implicit separation between deformation in both domains came out from these works, since most of the central belt thrusting was considered out-ofsequence with the structures in the foreland thrust-fold belt (e.g. Klepeis, 1994). With the incorporation of new data from the foreland, which led to Eocene-Miocene shortening estimates of tens of kilometers (Torres Carbonell et al., 2011, 2017a), it became clear that models explaining the connection between both ends of the orogenic system were increasingly needed.

One early approach to explain Cenozoic shortening in the foreland with coeval development of structures in the central belt was proposed by Torres Carbonell and Dimieri (2013). As a working hypothesis, these authors presented a schematic crosssection of the Fuegian Andes, combining the central belt and the foreland into a thrust-fold belt with basement involvement, in which a first-order duplex in the central 
97 belt transferred all the shortening recorded in the foreland (Fig. 1b). In this sense, even

98 if punctuated by successive deformation phases (or superposed generations of

99 structures) as previously suggested (Bruhn, 1979; Dalziel and Palmer, 1979; Nelson et

100 al., 1980; Cunningham, 1995; Klepeis et al., 2010), deformation in the Fuegian Andes

101 comprised a protracted history from the Late Cretaceous to the Miocene.

102 In this work we analyze previously published structural information from the

103 Fuegian Andes, and integrate it with new data that fill gaps in knowledge regarding the

104 age and style of deformation of the Argentine part of the orogen. Our new data

105 include detailed descriptions and cross-sections of two previously uncharted areas

106 where the relationships and superposition of the main phases of deformation in the

107 Fuegian Andes are well-revealed. We also include a detailed description of cross-

cutting relationships between two intrusive suites and deformation of their host rocks,

together with three new geochronological analyses of the youngest of these suites (of

110 previously unknown age), providing key temporal constraints on the timing of these

deformation phases in the Argentine Fuegian Andes. The critical appraisal of the

published information together with our new data, support the proposed scheme of

structural evolution of the orogen (Fig. 1b), with a first event comprising pre-

Maastrichtian collision, ductile deformation and metamorphism, and a second event

involving Maastrichtian-Danian to early Neogene faulting and uplift. The present study

validates the interpretation of the Fuegian Andes as a basement-involved regional 


\section{Regional geologic setting}

The origin of the Fuegian Andes involved the closure of a prior back-arc basin called Rocas Verdes Basin (Fig. 1b). This back-arc basin formed after Middle to Late Jurassic rifting of the southwestern margin of Gondwana, which preceded Early Cretaceous generation of oceanic floor between a volcanic arc and the continental margin. The basin was filled with marine successions during the Early Cretaceous (Dalziel et al., 1974; Dalziel, 1981; Stern and de Wit, 2003). Fragments of the oceanic floor are exposed as incomplete ophiolitic strips in the Tortuga, Sarmiento, and Capitán Aracena Complexes (Fig 1a), as well as intensely deformed and metamorphosed amphibolites at Cordillera Darwin (Cunningham, 1994; Stern and de Wit, 2003; Klepeis et al., 2010; Calderón et al., 2016). These ophiolitic rocks represent remnants of the Late Cretaceous collision between the magmatic arc and the continent during closure of the Rocas Verdes Basin (Nelson et al., 1980; Dalziel, 1986; Cunningham, 1994, 1995;

Klepeis et al., 2010). Near Cordillera Darwin, the ophiolitic rocks are highly strained, involved in mylonitic zones that have been interpreted either as related to convergent strike-slip deformation (Cunningham, 1995), or as thrust sheets reflecting northnortheastward obduction of part of the oceanic floor during basin closure (Klepeis et al., 2010). The Canal Beagle (Fig. 1a) manifests itself as a conspicuous structural boundary separating strongly deformed and metamorphosed rocks in Cordillera Darwin from less deformed and mainly magmatic rocks towards the south.

Closure of the Rocas Verdes Basin and further development of the Fuegian Andes also led to formation of a Late Cretaceous-Neogene foreland basin system in front of the orogen, called Austral basin (Magallanes in Chile, Biddle et al., 1986, Fig. 1a, b). Protracted deformation and development of the thrust-fold belt, therefore, affected 
syntectonic successions deposited in this basin. The stratigraphy of these successions as well as their overprinting relationships with the structures of the thrust-fold belt has been helpful to constrain several stages of uplift, erosion, and orogenic expansion (Torres Carbonell and Olivero, 2019). A more detailed description of the stratigraphy and a summary of the tectonic stages of the Fuegian Andes are given in the following sections.

\subsection{Stratigraphic framework}

The stratigraphic framework of the Fuegian thrust-fold belt is synthetically

described, focusing on lithologies and thicknesses involved in deformation, and

chronologic information useful to constrain structural stages (Fig. 2). For the sake of

brevity, we omit further detailed information that can be found in the cited references.

Throughout the text, we use formal names defined in Argentina for units that are also recognized in Chile, as shown in Fig. 2. For simplicity, we omit in our framework the back-arc mafic floor, which does not crop out in Argentina, as well as some intrusives of unknown age. portrays metamorphic grades from greenschist to upper amphibolite facies (Hervé et al., 2010a, 2010b). Within these metamorphic rocks, a distinction is made amongst the Mesozoic cover (Jurassic synrift deposits and Cretaceous sedimentites) and the "true basement" of the Rocas Verdes Basin (Figs. 2 and 3). The latter, composed mainly of phyllites, schists and metabasites, is characterized by pre-Permian detrital zircon ages 
169 (Hervé et al., 2010b). A single zircon U/Pb crystallization age of $153.12 \pm 0.93 \mathrm{Ma}$ from

170 a granite dike intruding a penetrative foliation in a schist at southern Cordillera Darwin

171 (Klepeis et al., 2010, see also Hervé et al., 2010b), constrains the pre-Jurassic

172 deformation of the basement (called $D_{B}$ by Nelson et al., 1980).

2.1.2. Jurassic synrift and Lower Cretaceous back-arc basin volcanic and

sedimentary rocks

\subsubsection{Lapataia Formation}

The Lapataia Formation (Figs. 2 and 3 ) includes greenschists facies

metasedimentites and metabasites that are thrust over the Upper Jurassic Lemaire

the Lapataia Formation is undetermined due to its intense deformation, unknown

base, and the tectonic nature of its contact with the Lemaire Formation. Recently

published structural and petrographic data suggest that this unit represents a highly

deformed section of the synrift Jurassic succession, stratigraphically between the

Paleozoic basement and the Lemaire Formation (Cao et al., 2018; see also Olivero et

al., 1997; Acevedo, 2019).

\subsubsection{Lemaire Formation}

The Lemaire Formation (Figs. 2 and 3), widely exposed in the central belt domain, is composed of very-low to low grade metasedimentary and metavolcanic-volcaniclastic rocks deposited during the synrift stage (Bruhn et al., 1978; Hanson and Wilson, 1991;

Olivero and Martinioni, 1996a; González Guillot et al., 2016; González Guillot, 2017; 
covered by the Lower Cretaceous Yahgan and Beauvoir formations, although a

detachment surface usually overprints this contact (Torres Carbonell and Dimieri,

2013; Cao et al., 2018). The total thickness of the Lemaire Formation is unconstrained.

$\pm 3.6 \mathrm{Ma}$ (Palotti et al., 2012). The equivalent Tobífera Formation (Fig. 2), by correlation

\subsubsection{Yahgan Formation}

The Yahgan Formation (Figs. 2 and 3) comprises very low-grade metasedimentary rocks, originated from marine epiclastic and volcaniclastic successions of the Rocas

Verdes Basin (Suárez and Pettigrew, 1976; Winn, 1978; Dalziel, 1981; Olivero and overprinted by a detachment surface (Torres Carbonell and Dimieri, 2013; Cao, 2019).

The top of the formation is unknown.

Estimations of the original thickness of the Yahgan Formation average from $1400 \mathrm{~m}$ near Ushuaia and increasing southwards (Winn, 1978; Caminos et al., 1981; Olivero and Malumián, 2008). The formation is not younger than the late Albian, according to its fossils and scarce geochronological data (Olivero and Martinioni, 1996b; Barbeau et al., 2009b).

\subsubsection{Beauvoir Formation}

The Beauvoir Formation (Figs. 2 and 3) comprises slates with a marine protolith, 
217 2008; Martinioni et al., 2013). South of Lago Fagnano, the contact with the underlying

218 Lemaire Formation is a few meters below a north-northeast-dipping detachment

219 surface (Torres Carbonell and Dimieri, 2013; González Guillot et al., 2016; Cao, 2019;

220 this work), whilst at Península Mitre this contact is a south-dipping reverse fault

221 (Torres Carbonell et al., 2017b). Its top is not well defined due to lack of stratigraphic

222 definition north of Lago Fagnano. A minimum thickness of $450 \mathrm{~m}$ has been estimated

223 for the formation, which contains Aptian-Albian marine invertebrates, mostly

224 inoceramids (Olivero et al., 2009; Martinioni et al., 2013).

succession of the Austral foreland basin (Figs. 2 and 3). The older rocks in this

succession include several mudstone-dominated units with Turonian-Campanian

fossils (Fig. 2, Olivero et al., 2009; Martinioni et al., 2013). The middle part of the

succession is formed by coarse-grained deposits interbedded with mudstones, of late

Campanian-?early Maastrichtian age according to ammonites and foraminifera (Bahía

Thetis Formation, Olivero et al., 2003). The youngest rocks in this package are

bioturbated fine sandstone-mudstone intercalations with Maastrichtian-Danian fossils and detrital zircon ages (Policarpo Formation, Olivero et al., 2002, 2003; Barbeau et al., 2009a; Martinioni et al., 2013).

The base of the Upper Cretaceous-Danian succession is not well-defined, whilst the top is marked by an unconformity between the Policarpo Formation and coarse 
240 deposits of the Río Claro Group (Fig. 2, Olivero et al., 2003; Martinioni et al., 2013). The

241 accumulated minimum thickness of the succession exceeds $1000 \mathrm{~m}$.

\subsubsection{Paleocene-lower Miocene succession}

The Paleocene to lower Miocene sedimentary rocks of the Austral basin comprise a

heterogeneous succession including several units that crop out, or are drilled in

subsurface, from the mountain front to northern Tierra del Fuego (Figs. 2 and 3).

Minimum estimated thicknesses of each unit are given in Fig. 2, from composite

sections. The base of this succession rests on an unconformity with the Policarpo

Formation (Olivero et al., 2003; Martinioni et al., 2013).

The upper part of the succession is formed by uppermost Oligocene-Miocene beds

coeval with the end of contraction in the thrust-fold belt (Torres Carbonell and Olivero,

2019). They include growth strata formed above the youngest folds (Ghiglione, 2002;

Malumián and Olivero, 2006; Ponce et al., 2008; Torres Carbonell et al., 2017a).

2.1.4. Fuegian batholith and peripheral intrusives north of Canal Beagle

\subsubsection{Darwin suite}

The oldest magmatic rocks north of Canal Beagle comprise orthogneisses mostly derived from granites intruded in the basement at Cordillera Darwin (Fig. 3, Nelson et al., 1980; Hervé et al., 1981, 2010b; Klepeis et al., 2010). The rocks are ductilely deformed and intruded by less deformed granitoids of the Beagle suite (Nelson et al., 


\subsubsection{Beagle suite}

The Beagle suite is the main unit of the Fuegian batholith (Fig. 3). North of Canal Beagle, the granitoids that compose this suite have $\mathrm{U} / \mathrm{Pb}$ zircon ages ranging between 86-74 Ma (Hervé et al., 1984; Klepeis et al., 2010; McAtamney et al., 2011). They postdate most of the ductile structures related to the arc-continent collision, although some intrusives overlap with the late stages of that deformation and the associated peak metamorphism (Maloney et al., 2011).

\subsubsection{Rear-arc suites}

\subsection{Ushuaia Peninsula Andesites}

The Ushuaia Peninsula Andesites (Fig. 3) include small ultramafic to silicic plugs cross-cut by a set of andesitic (the main lithology) and lamprophyre dikes (González Guillot et al., 2011). This suite intrudes the Yahgan Formation. One andesite dike yielded a zircon U/Pb age of $84.1 \pm 1.6 \mathrm{Ma}$ (González Guillot et al., 2018). The overprinting relationships between the Ushuaia Peninsula Andesites and the deformation of the Yahgan Formation are reported in this work as a constraint on deformation timing (see section 4.1.1).

\subsection{Fuegian Potassic Magmatism}

The Fuegian Potassic Magmatism comprises small $\left(<25 \mathrm{~km}^{2}\right)$, isolated plutons emplaced in the Yahgan and Beauvoir formations (Fig. 3, González Guillot et al., 2009). The plutons are composite, ranging from ultramafic to felsic facies, and with a characteristic mildly alkaline chemistry (González Guillot, 2016). The intrusives are the Ushuaia, Kranck, Moat and Jeu-Jepén plutons (Fig. 3). 
The Kranck pluton has especial interest for this work since it is associated with two

289

290

291

292

293

294

295

296

297

298

300

301

302

303

304

305

306

307

308

309

310

311

sets of dikes and sills (Cerro Rodríguez dikes) that intrude the Beauvoir Formation

towards the north of the pluton, within the internal thrust-fold belt domain (Torres

Carbonell et al. 2017c). We provide below (section 4.2), and later discuss, the

overprinting relationships of these dikes with the deformation of the host rock, as well as new geochronological data of the Kranck pluton and Cerro Rodríguez dikes (section

5). Previously reported $\mathrm{U} / \mathrm{Pb}$ zircon ages are $75 \pm 1.0 \mathrm{Ma}$ to $70.9 \pm 1.7 \mathrm{Ma}$ for the

Ushuaia pluton (Barbeau et al., 2009b; González Guillot et al., 2018), and $72.01 \pm 0.75$

Ma for the Jeu-Jepén pluton (Cerredo et al., 2011).

\subsection{Tectonic framework}

Contractional deformation in the Fuegian Andes started with the northward

obduction of the Rocas Verdes Basin oceanic floor in Cordillera Darwin, which was also associated with southward underthrusting of the continental margin of the basin, both processes comprising a first deformation phase in the region associated with arc-

continent collision (Fig. 1b, Klepeis et al. 2010). At mid-crustal depths, underthrusting and obduction caused high shear strain and peak metamorphism under upperamphibolite facies conditions, reaching $12 \mathrm{kbar}$ and $\sim 600^{\circ} \mathrm{C}$, and later decompressing to 9 kbar during peak temperatures of more than $600^{\circ} \mathrm{C}$. This is recorded in Bahía Pía (all localities shown in Fig. 3), where a high-grade shear zone has been described (Kohn et al., 1993, 1995; Klepeis et al., 2010; Maloney et al., 2011).

Modelled Ar/Ar ages of hornblende, muscovite, biotite and K-feldspar from metamorphic rocks of Cordillera Darwin indicate that first-phase deformation was ongoing by $90 \mathrm{Ma}$, with a stage of rapid cooling between 90-70 Ma (Fig. 4, Kohn et al., 
312 1995; see also Nelson, 1982). Other evidence of this rapid cooling trend, and

313 associated uplift and erosion of the orogenic core, is recorded in the Campanian-

314 ?lower Maastrichtian Bahía Thetis Formation and equivalent Cerro Matrero Formation

315 in Chile (Fig. 2). These units contain clasts of eroded metavolcanic and

316 metasedimentary rocks, and detrital zircons in the Cerro Matrero Formation with the

317 younger ages in the range of $82-145 \mathrm{Ma}$, derived from the back-arc basin fill, basaltic

318 floor and older synrift sequence (Fig. 4, Olivero et al., 2003; McAtamney et al., 2011).

319 The first-phase structures are intruded by Beagle suite granites without ductile

320 deformation, which suggests an age older than 86-74 Ma for this phase (Klepeis et al.,

321 2010). However, some contemporaneity between Beagle granite intrusions and first-

322 phase structures is indicated by an age of $72.6 \pm 2.2 \mathrm{Ma}$ from U-Th-Pb in-situ dating of

323 a late first-phase metamorphic monazite from Bahía Pía (Fig. 4, Maloney et al., 2011).

324 In Argentina, first-phase structures are intruded by the Ushuaia pluton, with a well-

325 developed contact-metamorphism aureole that overprints a previous foliation (Fig. 4,

326 González Guillot et al., 2018). In Península Mitre, the Bahía Thetis Formation is the

327 youngest unit affected by first-phase deformation (Fig. 4, Torres Carbonell et al., 2017b). This broadly suggests a late Campanian-?early Maastrichtian age for the end of this deformation phase.

The Beagle suite granites are affected by a second, more brittle deformation phase associated with at least three major thrust sheets in the Cordillera Darwin region (Klepeis et al., 2010). Similar structures from Argentina, and their relationship with the second phase, are reported in this work. The thrusts in Cordillera Darwin are responsible for uplift of the high-grade metamorphic rocks simultaneously with 
al., 2010; Maloney et al., 2011). Nonetheless, there are structures in Bahía Pía related

to retrogression of metamorphic assemblages (thus second-phase), which are cut by

the Beagle suite (F3/S3 in Klepeis et al., 2010). Therefore, we notice a possibly

contemporaneous development between early second-phase thrusting and intrusion

Beagle suite and the transition from the first collision-related phase and the second

thrust-related phase highlights the need for additional independent age constraints

from different portions of the Fuegian Andes. This is especially important to document

a possible diachronic progression of deformation in the orogen.

The second thrusting phase has been compared with the 60-40 Ma rapid cooling

trend modelled from Ar/Ar closure temperature ages on K-feldspar, hornblende,

muscovite, and biotite, $\mathrm{Rb} / \mathrm{Sr}$ closure temperature ages on biotite, and fission track

ages of titanite, zircon and apatite, from metamorphic rocks of Cordillera Darwin (Fig.

4, Kohn et al., 1995; see also Nelson, 1982). More recent zircon and apatite fission

track and (U-Th-Sm)/He ages of samples from southern Cordillera Darwin, Isla Gordon

and the Argentine central belt, suggest the onset of a rapid cooling stage since $\sim 48 \mathrm{Ma}$,

ending by $34 \mathrm{Ma}$ (Fig. 4, Gombosi et al., 2009). These cooling trends are consistent

with further uplift, erosion, and a more prominent supply of detritus eroded from the

basement and especially Jurassic components of the orogen to the foreland basin, as recorded from 150-180 Ma detrital zircons and from the petrography of Paleocene-

Eocene sedimentary rocks (Barbeau et al., 2009a; Torres Carbonell and Olivero, 2019).

Additional evidence of thrust-related uplift in the central belt comes from the 
Development of the foreland thrust-fold belt is coeval with both phases of

361

deformation in the central belt of the orogen (Fig. 4). The thrust-fold belt is subdivided into an internal and an external portion (Figs. 1a and 3), given their different structural styles (cf. Torres Carbonell et al., 2017a). Both portions and the central belt, however, are structurally linked, as we will discuss in this work.

The internal thrust-fold belt comprises structures between the central belt and a major structure called Apen-Malvinera thrust system (Fig. 3) that roughly defines the mountain front in Tierra del Fuego. Previous structural work in the internal thrust-fold belt has been published by Klepeis (1994), Zanella et al. (2014) and Torres Carbonell et al. (2013b, 2017b). The structure of the internal thrust-fold belt will be addressed in the following sections together with new structural and stratigraphic data from this region.

The external thrust-fold belt comprises the shallowest structures of the Fuegian Andes. These structures, as observed in seismic sections, are rooted in two main detachments localized below Paleocene strata and below the Cretaceous succession, respectively (Álvarez-Marrón et al., 1993; Zanella et al., 2014; Torres Carbonell et al., 2017a). Below these detachments, some deeper structures appear to be splays associated with the deep thrusts emplaced in the central belt (Torres Carbonell et al., 2017a).

The structures in the external thrust-fold belt have been interpreted as faultpropagation and fault-bend folds, with both foreland and hinterland vergence. Most of the thrusts are rarely exposed, except at the Apen-Malvinera thrust system and at the Atlantic coast, where few of them display cataclastic fabrics (Torres Carbonell et al., 
2011). No penetrative fabrics (foliations) have been recognized in the external thrust-

384

fold belt.

Several fracture sets, analyzed for paleostress directions, indicate compression perpendicular to most of the structures during the Paleogene (Maestro et al., 2019). In Península Mitre, on the other hand, the curvature of the thrust-fold belt forms a recess (Península Mitre recess). Based on fracture paleostress directions and strain measurements, this recess has been interpreted as a progressive arc with development of superposed deformations related to tangential longitudinal strain (Torres Carbonell et al., 2019).

In the Atlantic coast, previous work defined several contractional stages (Df2-Df6 in Fig. 4) based on the overprinting relationships of structures with well-exposed unconformity-bounded units (Torres Carbonell et al., 2011). The latter units, in turn, have well-constrained ages based on foraminifers, nanoplancton, dinocysts, and in some cases detrital zircon ages (Malumián and Olivero, 2006; Olivero and Malumián, 2008; Barbeau et al., 2009a; Torres Carbonell and Olivero, 2019).

These contractional stages, further grouped as D2 phase in Torres Carbonell et al. (2017a), developed from the early Eocene to the latest Oligocene-earliest Miocene. During these times, contractional deformation ceased simultaneously with deposition of growth strata in the deformation front (Df6, Fig. 4, Ghiglione, 2002; Torres Carbonell et al., 2011, 2013a).

According to balanced cross-sections, accumulated shortening in the Paleogene sequence vary between 11 and 28 km (16-45\%, Torres Carbonell et al. 2017a). Torres Carbonell and Dimieri (2013), and later Torres Carbonell et al. (2017a), argued that this shortening must necessarily be generated by transference of major structures in the 
407 hinterland, carried on ramps above the main detachments below the Cretaceous and

408 Paleocene sequences. According to this model, the second-phase structures of the

409 central belt are associated with uplift and transference of shortening to the foreland

410 through formation of an antiformal stack of basement and Upper Jurassic rocks (Fig.

411 1b, Torres Carbonell and Dimieri, 2013). The upper detachment of this first-order

412 duplex is located near the contact between the Upper Jurassic synrift sequences and

413 the Lower Cretaceous fill of the Rocas Verdes Basin (Klepeis, 1994; Kley et al., 1999;

414 Rojas and Mpodozis, 2006; Torres Carbonell and Dimieri, 2013; this work).

\section{Methods and new data}

New data used in this paper come from fieldwork in the Argentine Fuegian Andes.

Field data consist of attitudes and cross-cut relationships between different generations of structures, and between structures and several igneous bodies.

420 Oriented samples have been studied under the microscope in order to define metamorphic assemblages and/or microstructural relationships. In particular we present here detailed descriptions of two previously unmapped areas of the Fuegian Andes (located in Fig. 3): Cañadón Bianchi, at Montes Martial, and a cross-section along a creek in northern Sierra Alvear (Arroyo Velazquito). In these areas we obtained new supporting evidence for the superposition of younger, brittle-ductile thrustrelated structures on older ductile structures. All spherical projections shown were constructed with the software Stereonet 10.1.6 from R. W. Allmendinger. cutting relationships of selected intrusives that due to their position in the Fuegian 
431 hand, we studied the Ushuaia Peninsula Andesites, which constitute the southernmost

432 intrusives north of Canal Beagle in Argentine Tierra del Fuego, with an available

433 crystallization age. On the other hand, we studied the northernmost intrusives in the

434 thrust-fold belt: the Kranck pluton and related dikes and sills between the pluton and

435 Cerro Rodríguez (Cerro Rodríguez dikes). We present new structural descriptions, and

436 three new radiometric ages that constitute key constraints on the chronology of

437 deformation in the Fuegian thrust-fold belt.

$438 \mathrm{~A} \mathrm{U} / \mathrm{Pb}$ zircon age was obtained from a quartz monzonite of the Kranck pluton at

the Geochronology Laboratory of the University of Brasilia (Brazil), by LA-ICP-MS.

440 Other two hornblende Ar/Ar ages were obtained from a hornblendite of the Kranck

441 pluton, and from an undeformed hornblende lamprophyre from the Cerro Rodríguez

442 dikes, described in this work. Both Ar/Ar ages were obtained at the Earth Sciences

Institute at Orléans (ISTO), INSU-CNRS, University of Orléans (France), by step heating.

444 The methodological details and the tabulated results are given in the Supplementary

445 File 1.

A balanced cross-section is presented in section 7.2. This cross-section was constructed with Move 2018.2 software by sequential restoration of individual structures, with conservation of shortening transferred from deeper structures to shallower detachments as a premise. After initial construction, the cross-section was tested by forward modelling using Move-on-Fault tools in Move. The method selected was fault-bend folding, except from a few frontal structures modelled with trishear. 
455

456

457

458

459

460

461

462

463

464

465

466

467

468

469

470

471

472

473

474

475

476

477

478

\section{New structural data}

4.1. New structural data of the central belt

Our new structural data from the central belt includes detailed structural descriptions of, on one hand, the cross-cutting relationships between the Ushuaia Peninsula Andesites and deformation in their host rock, and on the other hand the superposition of brittle-ductile thrusts on prior ductile deformation, as well as the connection between these thrusts and a main upper detachment below the Cretaceous rocks. These latter brittle-ductile structures are described in two different areas of the central belt (Cañadón Bianchi and Arroyo Velazquito). Even though some thrusts and the detachment have been reported without much detail in other areas of the Fuegian Andes (e.g. Torres Carbonell and Dimieri, 2013; Torres Carbonell et al., 2017b), we provide here the first detailed description of these structures, and their superposed nature on previous ductile structures, in the area between Lago Fagnano and Canal Beagle.

\subsubsection{Deformation of the Ushuaia Peninsula Andesites}

The Ushuaia Peninsula Andesites were previously thought to postdate ductile deformation, based on unreported deformation or metamorphism in the intrusive rocks (González Guillot et al., 2011). Indeed, the host rock (Yahgan Formation), affected by contact metamorphism, preserves its original well-stratified character, without recognizable centimeter-scale folds (Fig. 5a-b) such as it is observed elsewhere surrounding Ushuaia, and along the Canal Beagle only a few kilometers away from Península Ushuaia (e.g. surrounding the Ushuaia pluton). Only occasionally the Yahgan Formation shows a spaced rough cleavage away from the main body of the intrusive 
479 suite (Fig. 5c). Farther away (> $1 \mathrm{~km}$ ), however, at the southeastern tip of the

480 peninsula, the Yahgan Formation reveals a more intense deformation, with

481 centimeter-scale folds and a closely spaced cleavage formed by pressure-solution

482 seams. At this location, an isolated, $1.5 \mathrm{~m}$ thick andesite dike, shows spaced pressure-

483 solution cleavage parallel to the foliation in the Yahgan Formation (Fig. 5d-f).

484 A comparison between the poorly deformed host rock, with only a spaced,

pressure-solution cleavage of stylolitic morphology (Fig. 5e-f), and the stronger

deformation in the Yahgan Formation away from the main intrusive, suggests that the

host rock has been protected from ductile deformation due to the existence of a

coherent, very competent igneous rock. The absence of penetrative structures in the stronger rheologies, with selective development in the weaker rocks, is typical of this part of the central belt, and consistent with the temperature conditions suggested by the low-grade metamorphism (see section 6.1).

492

At Montes Martial, in the area known as Cañadón Bianchi, we have mapped three brittle-ductile fault zones that constitute thrusts below a common upper detachment (Fig. 6a-b). The thrusts cut up-section metavolcaniclastic and metasedimentary rocks of the Lemaire Formation. These fault zones are composed of cohesive cataclastic rocks (Fig. 6c-d), with folded and deflected older foliations, forming characteristic s-c type fabrics with top-to-north shear sense (Fig. 6e). A clear superposition of these brittle-ductile structures on the prior ductile fabrics is observed in outcrop as well as under the microscope (Fig. 6f-g).The older foliations are continuous cleavages formed mostly by white micas and chlorite, as well as deformed quartz and plagioclase. In the 
503 metasedimentary facies this cleavage transposes bedding forming a characteristic

504 banded fabric (Fig. 6f).

505 The southernmost thrust joins a detachment located near the base of the Yahgan

506 Formation, just below a thick basic sill known as Puente Quemado Gabbro (described

507 in González Guillot et al., 2016, Fig. 6b). The detachment comprises a brittle-ductile

508 fault zone about 5 meters thick, characterized by cataclastic fabrics similar to the ones

509 described for the thrusts, but affecting in this case slates of the Yahgan Formation. A

510 notorious feature is the presence of faulted folds (classes 2 or $1 \mathrm{C}$ ) in the detachment

511 zone (Fig. 6h), as well as crenulation of the prior slaty cleavage (Fig. 6i). Kinematic

512 indicators (deflected foliation in s-c type fabrics) indicate top-to-north movement (Fig.

513 6j). Both the thrusts and the detachment are folded by first-order structures, and in a

514 SW-NE cross section they are involved in a large synform that plunges to the SE (Fig.

$5156 a, k)$.

516 At the northern face of Sierra Alvear, along Arroyo Velazquito, the same

517 detachment horizon is observed at the base of the Beauvoir Formation (Fig. 7). At this

518 location, the detachment surface is folded and exposed in the vertical, frontal limb of

519 an antiform affecting metavolcaniclastic facies of the Lemaire Formation, covered by

520 lapillitic mudstones of the Beauvoir Formation (Fig. 7a). Towards the north, the

521 Beauvoir Formation attains a gentle northward dip, thus the detachment dips below

522 Lago Fagnano in that direction (see Fig. 3). The detachment itself is characterized by

523 cataclastic fabrics, faulted folds, and deflected older foliations with s-c type fabrics

524 showing top-to-north shear sense (Fig. 7b-d, see also Fig. 8b). 


\subsection{New structural data of the internal thrust-fold belt}

We report here new detailed descriptions of the structures affecting Cretaceous rocks in the internal thrust-fold belt (Sierra Beauvoir), and their overprinting relationships with dikes intruding the Beauvoir Formation nearby Cerro Rodríguez (Cerro Rodríguez dikes, Fig. 9). The general deformation in this area has been described for the Upper Cretaceous rocks by Torres Carbonell et al. (2013b). Detailed descriptions of the deformation in older rocks have not been published so far, except from brief mentions in Torres Carbonell et al. (2017c). Further descriptions are included within the new data presented below.

Towards the lower stratigraphic horizons of Sierra Beauvoir (e.g. Beauvoir Formation), the rocks reveal a continuous cleavage formed mainly by very fine sericite. Folds across Sierra Beauvoir are involved in at least five orders, and in general they present NE vergence across the range. Wavelengths are of a few kilometers in the first order folds, and a few meters in the highest order (Fig. 8a). Competent beds form parallel folds, however multilayers can be classified as 1C or 2 Ramsay folds, since lesscompetent layers accommodate deformation forming class 3 folds between class 1B (parallel) competent folded beds. A wide spectrum in fold style is observed, however, with both angular and rounded hinges, and tightness varying between tight and open. At least three thrusts have been recognized at Sierra Beauvoir, involved in the stacking of the Cretaceous sequence. The thrusts have NE vergence, and occasionally cut the frontal limb of the first order folds. Thrusts are characterized by shear zones several tens of meters thick, where a deflection of prior cleavage planes or bedding (forming folds and s-c fabrics), disrupted stratigraphy, and widespread cataclastic fabrics are observed (Fig. 8b). Shear sense is always top-to-NE. These characteristics 
551 are similar to those described for thrusts affecting the same sequence in Chile (Klepeis,

552 1994), and at Península Mitre (e.g. Bahía Thetis thrust in Torres Carbonell et al.,

553 2017b).

554 Between Cerro Rodríguez and the Kranck pluton (Fig. 9) two distinct sets of dikes

555 and sills crop out (Cerro Rodríguez dikes, first reported by Martinioni et al., 1999). The

556 dikes intrude the Beauvoir Formation and have thicknesses of 0.2-2.5 $\mathrm{m}$. The

557 abundance of intrusions increases towards the Kranck pluton (Fig. 9). As briefly

558 reported by Torres Carbonell et al. (2017c), we identified two dike generations. One of

559 these generations is composed of clinopyroxene-biotite or clinopyroxene

560 lamprophyres, affected by spaced pressure-solution cleavage parallel to the

561 continuous cleavage in the host rock. These dikes are here called "deformed set" (Figs.

5629 and 10). The second generation has no cleavage and is composed of hornblende-

563 clinopyroxene lamprophyres and felsic dikes of andesite and trachy-andesite

564 ("undeformed set"). The deformed set is concentrated surrounding Cerro Rodríguez,

565 whereas the undeformed set has a more uniform distribution, but is more abundant

566 close to the Kranck pluton (Fig. 9). Martinioni et al. (1999) obtained a whole rock K/Ar

567 age of $104 \pm 4$ Ma for one undeformed, hornblende-phyric dike, which we discuss

568 below. On the basis of hornblende chemical composition, Acevedo et al. (2007)

569 correlated the hornblende undeformed dikes with hornblende gabbros from the

570 Kranck pluton.

572 5. Geochronological results

573 Sample BR47 (Fig. 9) is a quartz monzonite of the Kranck pluton, which lacks

574 penetrative deformation. Cross-cutting relationships indicate that it represents one of 
575 the youngest facies of the pluton (a thorough description of the facies was presented

576 by González Guillot et al., 2012). A total of 47 zircon grains were analyzed. The data set

577 shows a constant ${ }^{206} \mathrm{~Pb} /{ }^{238} \mathrm{U}$ age between 64 and $72 \mathrm{Ma}$, with a weighted average at

$57868.01 \pm 0.52 \mathrm{Ma}(2 \sigma, \mathrm{MSWD} 11.8$, Fig. 11a, Supplementary File 1). We interpret this as

579 the age of emplacement and crystallization of the rock.

580 Sample BR29 (Fig. 9) is an undeformed hornblendite from the Kranck pluton. It is

581 intruded by other facies, thus represents one of the earliest pulses of crystallization

582 (see more details in González Guillot et al., 2012). The sample has a weighted mean

583 age, integrated over the steps between arrows in Fig. $11 b$, of $73.4 \pm 1.6 \mathrm{Ma}(2 \sigma, \mathrm{MSWD}$

5840.81 , Supplementary File 1). Sample 104, an undeformed hornblende lamprophyre of

585 the Cerro Rodríguez dikes, has a weighted mean age, integrated over the steps

586 between arrows in Fig. 11c, of 74.0 $\pm 0.8 \mathrm{Ma}(2 \sigma, \mathrm{MSWD} 0.79$, Supplementary File 1$)$.

587 Both ${ }^{40} \mathrm{Ar} /{ }^{39} \mathrm{Ar}$ ages are indistinguishable; therefore the undeformed hornblende

588 lamprophyres of Cerro Rodríguez were emplaced at the same time than hornblendites

589 in the Kranck pluton, and before the quartz monzonite.

590

\section{Integration of previous and new structural data from the Fuegian thrust-fold belt}

In the following section we integrate our new structural and geochronological data

with previous work, which allows us to define structural generations and correlate

them across the Fuegian Andes. Based on previous work (Torres Carbonell and Dimieri, central belt from the internal thrust-fold belt. 
599

600

601

602

603

604

605

606

607

608

609

610

611

612

613

614

615

616

617

618

619

620

621

622

\subsection{Central belt}

The central belt of the Fuegian Andes reveal multiple generations of structures with complex correlations between different regions. This is especially so in the highly metamorphosed and deformed area of Cordillera Darwin, were glacier cover adds difficulty in connecting structures from different coastal outcrops. However, two major deformations can be roughly defined in Cordillera Darwin, called $\mathrm{D} 1_{\mathrm{CD}}$ and $\mathrm{D} 2_{\mathrm{CD}}$, each of them comprising one or more generations of structures. This distinction follows the criteria and data of Nelson et al. (1980), Cunningham (1995), Kohn et al. (1995), Klepeis et al. (2010), and Maloney et al. (2011), and correlates with the first and second deformation phases mentioned in section 2.2.

$D 1_{C D}$ comprises foliations and folds formed during the obduction and underthrusting of the oceanic floor and continental margin, respectively, with evidence of a southward-dipping mid-crustal shear zone nearby Bahía Pía (Nelson et al., 1980; Cunningham, 1995; Klepeis et al., 2010). This process formed an initial S1 metamorphic fabric and superposed S2 crenulation cleavage and F2 folds (Nelson et al., 1980; Kohn et al., 1993; Klepeis et al., 2010; Maloney et al., 2011), during what we interpret as a phase of progressive deformation with two generations of structures (S1 + S2/F2). Away from the zone of higher metamorphic grade at Bahía Pía, D1 $C D$ structures are limited to a single generation of S1 structures associated to top-tonortheast obduction and ductile shear (Nelson et al., 1980; Klepeis et al., 2010).

The second deformation, $\mathrm{D} 2_{\mathrm{CD}}$, includes crenulation, kink bands, thrusts and folds that deform the prior $\mathrm{D} 1_{\mathrm{CD}}$ structures. At Bahía Pía and in northern Cordillera Darwin $\mathrm{D} 2_{\mathrm{CD}}$ structures have NE vergence and are coeval with retrograde metamorphism (Nelson et al., 1980; Kohn et al., 1993). West of Bahía Pía (at SW Cordillera Darwin) 
$623 \mathrm{D} 2_{\mathrm{CD}}$ structures are associated with backfolds and backthrust shear zones (Klepeis et

624 al., 2010). D2 $2_{C D}$ developed during uplift of Cordillera Darwin, caused by at least three

625 identified major thrusts (Garibaldi -blind-, Parry and Marinelli thrusts, Fig. 3), which

626 together with the backfolds and backthrusts recognized in SW Cordillera Darwin form a

627 doubly-vergent wedge (Nelson et al., 1980; Klepeis et al., 2010).

628 Formation of $\mathrm{D} 1_{\mathrm{CD}}$ structures, as detailed in section 2.2 , started before $\sim 90 \mathrm{Ma}$

629 (Kohn et al., 1995) and acted at least until $73 \mathrm{Ma}$, coeval with the last intrusions of

630 the Beagle suite (Fig. 4, Klepeis et al., 2010; Maloney et al.,2011; McAtamney et al.,

631 2011). Thus, mid-crustal shearing during $D 1_{C D}$ may be transitional with the beginning of

632 thrusting during the following deformation $\left(D 2_{C D}\right)$, which has ambiguous overprinting

633 relationships with the Beagle suite (Klepeis et al., 2010).

634 The thrusting stage related to $\mathrm{D} 2_{\mathrm{CD}}$ progressed through the Paleogene, as evidenced

635 by thermochronology results detailed in section 2.2 (Fig. 4, Kohn et al., 1995; Gombosi

636 et al., 2009). An appraisal of previous work, however, shows no clear connection with

637 the structures towards the foreland, which have been interpreted as structures formed

638 prior to out-of-sequence uplift of Cordillera Darwin (Klepeis, 1994; Kley et al., 1999;

639 Klepeis et al., 2010).

640 In Argentine Tierra del Fuego, overprinting structural relationships from the central

belt also allowed to define two main structural styles. An older, ductile deformation,

which we will call $\mathrm{D} 1_{\mathrm{CB}}$ (first deformation -D1- recorded in the central belt -CB-

excluding Cordillera Darwin), and a younger, brittle-ductile deformation that we call 
647 1932; Bruhn, 1979; Dalziel and Palmer, 1979; Torres Carbonell and Dimieri, 2013;

648 Torres Carbonell et al., 2017b; Cao et al., 2018; Cao, 2019). Between Canal Beagle and

649 Lago Fagnano, $\mathrm{D} 1_{\mathrm{CB}}$ folds range from tight or isoclinal in the Lapataia and Lemaire

650 formations, to tight or very tight folds with NE vergence, usually classes $1 \mathrm{C}$ to 2 , in the

651 Yahgan and Beauvoir formations. The axial-plane foliation is defined by low-grade

652 metamorphic minerals, and occasionally transposes bedding (Fig. 8a). An exception

653 occurs in the more competent coherent volcanic-subvolcanic bodies of all the

654 formations of this region of the central belt, in which the folds and cleavage are not

655 uniformly developed; some of these bodies show poor cleavage or none at all. The

656 metamorphic grade in this part of the central belt is within prehnite-pumpellyite to

657 greenschist facies (Bruhn, 1979; Cao et al., 2018; Cao, 2019).

In the zones of higher strain, especially localized in quartz-rich lithologies, the main

structures are mylonitic fabrics with top-to-north or northeast shear sense (Fig. 8a).

660 These mylonites, first recognized by Kranck (1932) and Bruhn (1979), led the latter

author to interpret formation of the central belt between Canal Beagle and Lago

Fagnano as a result of progressive simple shear. An alternative interpretation based on scattered and undetailed data suggested that these mylonites formed part of the $D 2{ }_{C D}$ thrusting of Cordillera Darwin (Torres Carbonell and Dimieri, 2013). However, as will be addressed below, the correlation of the $\mathrm{D} 2_{\mathrm{CD}}$ brittle-ductile structures with the brittleductile thrusts reported in section 4.1.2, suggests that these mylonites are older. et al., 2018). 
670 In southern Península Mitre, the $\mathrm{D} 1_{\mathrm{CB}}$ structures and metamorphic grades in the

671 Lemaire and Beauvoir formations are similar to those between Lago Fagnano and

672 Canal Beagle, with a NW-SE structural trend (Torres Carbonell et al., 2017b). Moreover,

673 in this region it is clear how the intensity of the $D 1_{C B}$ structures decrease from

674 mylonitic foliations and transposition cleavage to spaced pressure-solution cleavage

675 towards upper structural levels, affecting rocks as young as late Campanian-?early

676 Maastrichtian (Bahía Thetis Formation, Figs. 2 and 8a, Torres Carbonell et al., 2013b,

677 2017b). These NW-SE structures are included in the first deformation phase of Torres

678 Carbonell et al. (2017b).

679 Previous constraints on the age of the $\mathrm{D} 1_{\mathrm{CB}}$ structures were limited to their

680 inclusion in the "main phase of deformation" ("mid" Cretaceous in Bruhn, 1979; Dalziel

681 and Palmer, 1979), and the statement that they affected rocks not younger than the

682 Campanian-?Maastrichtian Bahía Thetis Formation (Torres Carbonell et al., 2017b).

683 González Guillot et al. (2018) established that these structures are older than the

684 Ushuaia pluton (75-71 Ma), giving a stronger constraint for the southern portion of the

685 central belt (Fig. 4). The same overprinting relationship is observed in other pluton of

686 the Fuegian Potassic Magmatism, the Jeu-Jepén pluton, which has a contact

687 metamorphism aureole that overprints cleavage in the host rocks (Fig. $5 \mathrm{~g}$ ).

688 The deformed dike depicted in Fig. $5 \mathrm{~d}$-f confirms that ductile structures $\left(\mathrm{D} 1_{\mathrm{CB}}\right)$

689 affected the Ushuaia Peninsula Andesites. From correlation of that dike with the dated

690 andesite at the main body of the intrusion (84.1 $\pm 1.6 \mathrm{Ma}$, González Guillot et al.,

691 2018), we can establish an oldest time constraint on the age of these structures (Fig.

$6924)$. 
The younger deformation, $\mathrm{D} 2_{\mathrm{CB}}$, includes large folds (up to tens of kilometers of

694

wavelength) and crenulation cleavages that grade from a pervasive development in the lower structural levels (Lapataia Formation), to spaced crenulation cleavages localized in high-strain zones in the upper structural levels (Bruhn, 1979; Cao et al., 2018). These high-strain zones comprise thrusts and detachments (Fig. 8b), the former include the thrust zones of Cañadón Bianchi (section 4.1.2), as well as thrusts previously reported at the contact between the Lapataia and Lemaire formations (Beatriz thrust, Fig. 3, Cao et al., 2018; Cao, 2019), within the Lemaire Formation at Sierra Sorondo and Sierra Alvear (Cao, 2019), and between the Lemaire and Beauvoir formations at Montes Negros (Torres Carbonell et al., 2017b). The detachments are consistently located in the surroundings of the contact between the Lemaire and Yahgan or Beauvoir formations, as stated in section 4.1.2 (cf. Torres Carbonell and Dimieri, 2013; Cao, 2019). In Chile, the same detachment level was identified between the Tobífera and Río Jackson formations and has been called Río Jackson detachment by Klepeis (1994).

The $\mathrm{D} 2_{\mathrm{CB}}$ thrusts form characteristic zones of protracted deformation during decreasing temperature conditions. Accordingly, while crenulation cleavages and deflected foliations formed in the lower structural levels, these structures were overprinted by cataclastic fabrics in shallower levels. For example, as shown in Fig. $6 \mathrm{f}$, ductile $\mathrm{D} 2_{\mathrm{CB}}$ folds affecting the older $\mathrm{D} 1_{\mathrm{CB}}$ transposition foliation are faulted and incorporated in a brittle $\mathrm{D} 2_{\mathrm{CB}}$ cataclasite. In the more brittle settings and especially near detachment horizons, the crenulations affecting previous $\mathrm{D} 1_{\mathrm{CB}}$ foliations are localized within a few meters from the detachment surfaces or shear zones, and dissipate away from the fault surfaces (Fig. 8b). Our data from Cañadón Bianchi and 
717 Arroyo Velazquito (Figs. 6 and 7) confirm the superposition of these thrusts and

718 detachment on the prior ductile $\mathrm{D} 1_{\mathrm{CB}}$ deformation, thus constraining $\mathrm{D} 2_{\mathrm{CB}}$ to a post-

719 Campanian age (Fig. 4).

720 A third generation of structures in the Argentine central belt has been described by

721 Cao (2019) and Cao et al. (2018), characterized by small (cm-scale) folds, kink bands

722 and shear zones of deflected $\mathrm{D} 1_{\mathrm{CB}}$ cleavage. These structures consistently have a N-S

723 orientation, which is almost perpendicular to the regional structural trend. They have

724 been interpreted as a distinct phase by the cited authors, but it is also possible that

725 they are cross-folds or similar structures (see for example Butler, 1982) formed during

726 the same $\mathrm{D} 2_{\mathrm{CB}}$ deformation.

727

\subsection{Internal thrust-fold belt}

The connection between the central belt and the internal thrust-fold belt has been described north of Seno Almirantazgo and Lago Fagnano, in Chile (Klepeis, 1994; Kley et al., 1999; Rojas and Mpodozis, 2006). This connection, as mentioned in the previous section, involves a detachment at the base of the Lower Cretaceous shaly sequence, mapped as the Río Jackson detachment by Klepeis (1994) and reported in Argentina in this work (Fig. 7). Previous work by Klepeis (1994) and Torres Carbonell and Dimieri (2013), defined this detachment as the base of the cover sequence deformed in the foreland thrust-fold belt (Fig. 8b). and refolding of these structures by open folds (F2). Both generations developed, 
741 emplacement in the Cretaceous succession. Thrusts in this region are recognized as

742 brittle-ductile structures such as s-c type, and brittle cataclastic fabrics. Klepeis (1994)

743 also interpreted two backthrusts, associated with deformation just above the Río

744 Jackson detachment.

745 At Sierra Beauvoir, the Upper Cretaceous rocks are deformed by folds and an axial-

746 plane foliation, both with variable degrees of development (Torres Carbonell et al.,

747 2013b). The foliation varies from smooth disjunctive cleavage in the lower structural

748 levels or high-strain zones, to a more spaced cleavage $(>0,05 \mathrm{~mm})$ formed by

pressure-solution in the uppermost part of the succession. In the Policarpo Formation,

for example, the cleavage is absent or very roughly developed and usually it is only a

pencil structure (Torres Carbonell et al., 2013b). Our new data from the internal thrust-

fold belt (section 4.2) complements these previous descriptions from Sierra Beauvoir,

metamorphism in the older units. We recognized no backfolds or backthrusts,

however, which could have been correlated with similar structures described in Chile,

just tens of kilometers west of our study area (cf. Klepeis, 1994). et al. (2017b). These structures comprise NE-SW oriented folds, brittle-ductile shear zones (e.g. Bahía Thetis thrust and Buen Suceso backthrust) and SE-dipping pressuresolution cleavages in the Policarpo Formation and older Upper Cretaceous rocks, which grade to crenulation cleavages in the Beauvoir and Lemaire formations further south. No significant growth of metamorphic minerals is associated with the formation of this crenulation. The thrusts are characterized by zones several hundred meters thick, 
765 integrated by shear fabrics superposed on the prior $D 1_{C B}$ foliation. These include $s-C$

766 type fabrics and disrupted strata, evidencing deformation in brittle-ductile conditions

767 (Torres Carbonell et al., 2017b).

768 Both at Península Mitre and Sierra Beauvoir, the youngest spaced cleavages affect

769 the Policarpo Formation. The Paleocene Río Claro Group, resting on an unconformity

770 above the Policarpo Formation, lacks penetrative deformation (Torres Carbonell et al.,

771 2013b). This led to define a deformation phase of approximately Danian age (D1 in

772 Torres Carbonell et al., 2017a), which in Península Mitre cross-cuts the prior D1 $1_{C B}$

773 structures with a highly oblique trend (NE-SW against NW-SE). Here we call this

774 deformation $\mathrm{D} 1_{\mathrm{FB}}$, namely the first deformation distinct to the foreland thrust-fold belt

775 (FB, Fig. 4).

776 At Sierra Beauvoir, where both $\mathrm{D} 1_{\mathrm{CB}}$ and $\mathrm{D} 1_{\mathrm{FB}}$ are coaxial (NW-SE trend), their

777 distinction is aided with our new geochronological data (section 5). The age of sample

778104 is significantly younger than the age obtained for a similar undeformed dike by

779 Martinioni et al. (1999) using K/Ar in whole rock. We consider our age better

780 constrained, whereas previous work in the Fuegian Andes has shown the significant

781 errors associated with K/Ar dating (González Guillot et al., 2018). Therefore, our new

782 age allows us to place the formation of foliations in the deformed set of the Cerro

783 Rodriguez dikes and host rock before $\sim 74 \mathrm{Ma}$, placing these structures in the $\mathrm{D} 1_{\mathrm{CB}}$

784 deformation. In this manner, younger spaced cleavages affecting rocks as young as the

785 Policarpo Formation, mentioned before, can be attributed to $\mathrm{D} 1_{\mathrm{FB}}$ consistently with

786 the assignment made in Península Mitre (cf. Torres Carbonell et al., 2017b). Younger

787 deformations in the foreland (Df2-Df6, mentioned in section 2.2), which are not

788 discussed in this work, are grouped within a single deformation D2 $2_{\mathrm{FB}}$ (Fig. 4). 
789

790

791

792

793

794

795

796

797

798

799

800

801

802

803

804

805

806

807

808

809

810

811

812

\section{Protracted deformation history of the Fuegian thrust-fold belt}

The combination of published and new data just presented allows us to integrate the central belt and the foreland thrust-fold belt of the Fuegian Andes in a protracted deformation history, from the Late Cretaceous to the early Neogene. The evidence for structural connections between the central belt and the internal thrust-fold belt, in turn linked with the external thrust-fold belt, permits to analyze these portions of the orogenic front in a coherent manner, using as an example the restored cross-section presented below.

We propose a simplified, regional deformation sequence in which distinct structural styles develop simultaneously at different portions of the orogenic belt. Accordingly, the phases and stages of deformation mentioned throughout this text, which group generations of structures in different sectors of the thrust-belt, are here included in two major events forming this protracted history. The first event (red double-arrows in Fig. 4) involved the closure of the back-arc basin leading to obduction, underthrusting, and arc-continent collision (cf. Nelson et al., 1980; Dalziel, 1986; Cunningham, 1995; Klepeis et al., 2010), during which the orogeny was initiated. The second event (black double-arrows in Fig. 4) involved major uplift of the orogenic core (central belt) leading to formation of a first-order thrust system (antiformal stack) that transferred shortening towards the foreland, expanding the thrust-fold belt into the coeval foreland basin system (cf. Torres Carbonell and Dimieri, 2013).

\subsection{First event: Arc-continent collision}

Our new data on the overprinting relationships between the Ushuaia Peninsula Andesites and the $\mathrm{D} 1_{\mathrm{CB}}$ deformation (Fig. $5 \mathrm{~d}$-f) indicates an age not older than $\sim 84 \mathrm{Ma}$ 
813 for the first event in the southern central belt in Argentina (Fig. 4). The youngest age of

$814 D 1_{C B}$ in the same area has already been established by the intrusion of the Ushuaia

815 pluton by 75-71 Ma (González Guillot et al., 2018), which is consistent with the

816 Campanian age determined in Península Mitre (first phase in Torres Carbonell et al.,

817 2017b). At the northern border of the central belt, the $72 \mathrm{Ma}$ Jeu-Jepén pluton

818 (Cerredo et al., 2011) also overprints the $\mathrm{D} 1_{\mathrm{CB}}$ foliation (Fig. 5g).

819 Even if these temporal constraints are consistent with the correlation of $\mathrm{D} 1_{\mathrm{CB}}$ and

$820 \mathrm{D} 1_{C D}$, the beginning of ductile deformation in the Argentine part seems to have been

821 delayed in comparison with the development of deep-seated structures in Cordillera

822 Darwin, which started before $90 \mathrm{Ma}$ (Fig. 4). In addition, during the end of the

823 collisional event (by $\sim 73 \mathrm{Ma}$ ), deformation in Cordillera Darwin occurred under high-

824 temperature conditions, coincident with decompression from 12 to 9 kbar and

825 initiation of thrust-related uplift (Maloney et al., 2011). Conversely, the coeval

826 deformation between Canal Beagle and Lago Fagnano was milder, especially in the

827 upper stratigraphic levels (Yahgan-Beauvoir formations). This is notorious within and

828 around some competent rock bodies that developed poor cleavage or were almost

829 undeformed (Fig. 5a-d). The more deformed rocks in this region, indeed, are

830 represented by low-grade mylonitic zones in the Lapataia and Lemaire formations (Fig.

831 8a). This is consistent with a change from high- to low-grade deformation across the

832 orogen, i.e. from the internal and lower structural levels now exposed at Cordillera

833 Darwin to the external, upper structural levels exposed between Lago Fagnano and

834 Canal Beagle. Farther towards the Campanian deformation front, in the internal thrust-

835 fold belt, only very low-grade deformation affects the Beauvoir Formation. 
The data presented here in section 4.2 also contribute to constrain the age of the

837 collisional event in the internal thrust-fold belt. Accordingly, the age of the

838 undeformed set of the Cerro Rodríguez dikes constrains the age of collisional

839 deformation in that region to before $\sim 74 \mathrm{Ma}$ (Fig. 11), which is consistent with the ages

840 in the central belt.

841 In summary, the progression of deformation during the arc-continent collision event

842 can be described as foreland directed, ductile simple shear deformation above the underthrusting continental plate, concurring with Bruhn (1979, see also Tanner and Macdonald, 1982; Storey, 1983, Fig. 8a). Whilst high-grade deformation started prior to $90 \mathrm{Ma}$ in Cordillera Darwin $\left(\mathrm{D} 1_{\mathrm{CD}}\right)$, in the Argentine Fuegian Andes only the last, Campanian part of this deformation is recorded in the rock structures, comprising low-

847 grade deformation $\left(\mathrm{D} 1_{\mathrm{CB}}\right)$.

\subsection{Second event: Major thrusting and expansion of the orogenic wedge}

Our new data from the central belt contributes to the definition of the second event during the orogenic history, which involved thrust-related deformation throughout the orogen. We presented evidence from Cañadón Bianchi (Fig. 6) which confirms part of the thrust faults forming the duplex proposed by Torres Carbonell and Dimieri (2013). This new evidence adds to previous data reported by Torres Carbonell et al. (2017b) and Cao et al. (2018). These thrusts, ramping from an unexposed lower detachment

856 (possibly located in the basement unit), cut through Jurassic syn-rift deposits and join an upper detachment in the vicinity of the contact between the Lemaire and Yahgan or 
859 superposed on previous ductile $\mathrm{D} 1_{\mathrm{CB}}$ structures; therefore they post-date the

860 Campanian (Fig. 4).

861 In a similar way, the $\mathrm{D} 1_{\mathrm{CD}}$ structures are overprinted by $\mathrm{D} 2_{\mathrm{CD}}$ structures in Cordillera

862 Darwin, which are related to ductile-brittle thrusts emplaced in that region. The

863 northernmost of these thrusts, called Marinelli thrust (Klepeis, 1994), can be laterally

864 traced to join the Beatriz thrust in our map (Fig. 3). Klepeis (1994) suggested that the

865 Marinelli thrust exhumed and placed basement rocks on top of back-arc basin cover

866 rocks, proposing that the thrust timing was out-of-sequence with deformation in the

867 internal thrust-fold belt. Building on that interpretation, it has been proposed that all

868 the D2 $2_{C D}$ thrusts (Garibaldi, Parry and Marinelli) formed out-of-sequence with the

869 internal thrust-fold belt (Kraemer, 2003; Rojas and Mpodozis, 2006; Klepeis et al.,

870 2010). This has important implications for the transference of shortening (or lack of it)

871 that built the foreland portion of the thrust-fold belt.

872 An alternative view has been proposed by Torres Carbonell and Dimieri (2013),

873 interpreting the Marinelli thrust as a ramp which, after being actively involved in the

874 duplex, broke up-section as a breaching thrust (cf. Butler et al., 2007), cutting the

875 duplex roof detachment. This interpretation is more adequate to allow additional

876 structures in the hinterland to transfer shortening to the foreland, before being

877 effectively uplifted above the roof thrust (see also Torres Carbonell et al., 2017a).

878 Our interpretation for the progression of $D 2_{C B}$ structures is shown in a balanced

879 cross-section constrained by field and seismic data (Fig. 12). This cross-section uses a

880 depth to the basal detachment controlled by depth-migrated seismic data and wells in

881 the foreland, and with an arbitrary uniform dip towards the hinterland. Notice that the 
basement-Upper Jurassic contact in the cross-section is speculative. Further details on the balancing method are given in section 3 .

884 The cross-section assumes that all the deformation during $\mathrm{D} 2_{\mathrm{CB}}$ was accommodated 885 by movement on single thrusts. This clearly is an oversimplification, but allows creating 886 a geologically reasonable and viable cross-section that explains the first-order central 887 belt structure and coeval foreland deformation. It also implies amounts of shortening transferred to the foreland that are consistent with balanced cross-sections in the external thrust-fold belt (Torres Carbonell et al., 2017a).

brittle-ductile thrusts in the central belt during $\mathrm{D} 2_{\mathrm{CD}}$ and $\mathrm{D} 2_{\mathrm{CB}}$ progressed

simultaneously with accommodation of transferred shortening in shallower structures in the thrust-fold belt ( $\mathrm{D} 1_{\mathrm{FB}}$ and $\mathrm{D} 2_{\mathrm{FB}}$, Fig. 8b). The latter argument is consistent with the cooling history of the central belt, as reported in section 2.2 , which indicates coeval uplift of the central belt and deformation in the foreland at least during the Late the central belt after the initial closure of the Rocas Verdes Basin, also implies the existence of basement thrust wedges below the central belt as a requisite to explain the structural level at which the Lemaire Formation is uplifted, in comparison with the same horizons in the foreland (Fig. 12). This interpretation has the advantage of explaining the occurrence of rocks uplifted from depths of more than $20 \mathrm{~km}$ (12 kbar and $\sim 60{ }^{\circ} \mathrm{C}$ according to Kohn et al. 1995) at the current surface (at Bahía Pía), using a reasonable geometric model for this amount of uplift. 
Conditions of deformation during the thrusting event varied also with structural

906 position. In the central belt the metamorphic grade was low in Cordillera Darwin (Kohn

907 et al., 1993), to very low or even absent in Argentina, and penetrative deformation was

908 restricted to crenulation cleavages with minor growth of retrograde metamorphic

909 minerals associated with the formation of major brittle-ductile thrusts (Fig. 8b).

910 Towards the foreland, shortening transferred from the duplex to the Cretaceous cover

911 was accommodated by pressure-solution and spaced cleavage development, followed

912 by folding and brittle-ductile thrusting (Fig. 8b). This deformation comprises, in the

913 scheme presented here, the $\mathrm{D} 1_{\mathrm{FB}}$ structures now exposed in the internal thrust-fold

914 belt.

915 Simultaneous sedimentation and deformation in the Austral basin characterized the

916 following deformation in the external part of the thrust-fold belt, called D2 ${ }_{F B}$ in this

917 work. This deformation is mostly related to the development of major thrust systems

918 in the foreland until the early Miocene (Fig. 12, see Torres Carbonell et al., 2017a).

\section{Conclusions}

An integration of new structural and geochronological data with an analysis of

922 previously published data from the Fuegian Andes, allows us to document the sequence of deformation within a tectonic model of the orogen formed in the southernmost Andes. Accordingly, we constrain the timing of the two main events involved in deformation in the Argentine portion of the orogen. The first event was caused by closure of the Rocas Verdes Basin, with obduction, underthrusting, and arccontinent collision. As previously documented from Cordillera Darwin, this event spanned from ca. 100-90 Ma to ca. $73 \mathrm{Ma}$ ago, causing high-grade deformation (e.g. 
929 Kohn et al., 1995; Maloney et al., 2011). However, in the central belt in Argentina, our

930 new data reveal that only Campanian (post-84 Ma), low-grade structures were

931 developed in the uppermost structural levels of the collision-related deformation. This

932 deformation is also recorded in the internal thrust-fold belt, and we provide a new age

933 constraint for the structures in that region, which are post-dated by intrusives with

934 Ar/Ar hornblende ages of $74 \mathrm{Ma}$.

935 The second event was characterized by the formation of a first-order thrust system

936 since the Maastrichtian-Danian. This led to the definitive formation and expansion of

937 the thrust-fold belt until the early Miocene, with major uplift episodes recorded in the

938 hinterland associated with the emplacement of major basement-involved thrust

939 sheets. Our new structural data confirms the occurrence of these thrusts, and their

940 connection with a common upper detachment placed at the base of the Lower

941 Cretaceous rocks, which forms the roof thrust of a major duplex in the central belt.

942 This scheme explains the different styles of deformation across the Fuegian Andes

943 in the context of a progressive evolution from collisional-style orogenesis to thrust-

944 related deformation. This model also allows explaining the shortening in the deformed

945 Austral-Magallanes foreland basin as a consequence of major thrust emplacement in

946 the central belt. Our new structural and geochronological data, in addition, give key

947 constraints to correlate structure generations across and along the strike of the

948 orogen.

\section{Acknowledgements}

951 Financed by ANPCyT-FONCYT PICT 20152982 and 0419, PUE CONICET 2016, and

952 CTM2017-89711-C2-2-P from the Ministry of Science, Innovation and Universities of 
953 Spain. Work in the Parque Nacional Tierra del Fuego was granted by permit APN-049-

954 DRPA. Special thanks to M. Barbagallo (CADIC) for preparation of thin sections, and to

955 M. Escayola and the late M. Martins Pimentel for generous discussion of geochemical 956 and geochronological data. We are indebted to I. Menéndez Behety, A. Imbert, and

957 families Pastoriza and Pechar for their generous logistic support and accommodation.

958 Help in the field by F. Torres Carbonell and D. Pereira is much appreciated. We

959 acknowledge the license of the MOVE Software Suite granted to CADIC by Petroleum

960 Experts Ltd. We thank V. Ramos and an anonymous reviewer for their suggestions,

961 which were very helpful to improve this manuscript.

\section{References}

Acevedo, R.D., 2019. Geological Records of the Fuegian Andes Deformed Complex

Acevedo, R.D., Valín-Alberdi, M.L., González Guillot, M., Elsztein, C., 2007. Whole rock and mineral chemistry of mafic dykes from Beauvoir range, Tierra del Fuego, In: International congress on the geology and geophysics of the southern hemisphere. Abstracts volume. Centro de Extensión, Pontificia Universidad Católica de Chile, Santiago de Chile, p. 4.

Álvarez-Marrón, J., McClay, K., Harambour, S., Rojas, L., Skarmeta, J., 1993. Geometry and evolution of the frontal part of the Magallanes foreland thrust and fold belt (Vicuña Area), Tierra del Fuego, Southern Chile. AAPG Bulletin 77, 1904-1921. 
basin: implications for Eocene kinematics of the northern Scotia Arc and Drake

979 Barbeau, J., David L., Gombosi, D.J., Zahid, K.M., Bizimis, M., Swanson-Hysell, N.,

980 Valencia, V., Gehrels, G.E., 2009b. U-Pb zircon constraints on the age and

981 provenance of the Rocas Verdes basin fill, Tierra del Fuego, Argentina. Geochemistry, Geophysics, Geosystems 10, Q12001.

Biddle, K., Uliana, M., Mitchum Jr., R., Fitzgerald, M., Wright, R., 1986. The stratigraphic and structural evolution of the central and eastern Magallanes Basin, 66.

Bruhn, R.L., 1979. Rock structures formed during back-arc basin deformation in the Andes of Tierra del Fuego. Geological Society of America Bulletin 90, 998-1012.

Bruhn, R.L., Stern, C.R., de Wit, M.J., 1978. Field and geochemical data bearing on the development of a Mesozoic volcano-tectonic rift zone and back-arc basin in southernmost South America. Earth and Planetary Science Letters 41, 32-46.

Butler, R.W.H., 1982. Hangingwall strain: A function of duplex shape and footwall topography. Tectonophysics 88, 235-246.

Butler, R.W.H., Matthews, S.J., Morgan, R.K., 2007. Structural evolution of the Achnashellach Culmination, southern Moine Thrust Belt: testing the duplex model. Geological Society, London, Special Publications 272, 103-120.

Calderón, M., Hervé, F., Fuentes, F., Fosdick, J.C., Sepúlveda, F., Galaz, G., 2016. Tectonic Evolution of Paleozoic and Mesozoic Andean Metamorphic Complexes and the Rocas Verdes Ophiolites in Southern Patagonia, In: C. Ghiglione, M. (Ed.), 
Geodynamic Evolution of the Southernmost Andes: Connections with the Scotia Arc. Springer International Publishing, Cham, pp. 7-36.

1003 Caminos, R., Haller, M.J., Lapido, O., Lizuain, A., Page, R., Ramos, V., 1981.

1004 Reconocimiento geológico de los Andes Fueguinos. Territorio Nacional de Tierra del 1005 Fuego, Actas VIII Congreso Geológico Argentino, San Luis, pp. 759-786.

Cañón, A., 2000. Nuevos antecedentes en la estratigrafía de la Cuenca de Magallanes. Anales Instituto de la Patagonia 28, 41-50.

Cao, S.J., 2019. Estructura y estratigrafía del Jurásico Superior-Cretácico entre el Canal Beagle y el Lago Fagnano, Tierra del Fuego, Argentina. PhD thesis, Departamento de Geología, Universidad Nacional del Sur, Bahía Blanca, 313 pp.

Cao, S.J., Torres Carbonell, P.J., Dimieri, L.V., 2018. Structural and petrographic constraints on the stratigraphy of the Lapataia Formation, with implications for the tectonic evolution of the Fuegian Andes. Journal of South American Earth Sciences $84,223-241$.

Cerredo, M.E., Tassone, A., Rapalini, A., Hervé, F., Fanning, M., 2011. Campanian magmatism in the Fuegian Andes: new SHRIMP age of Jeujepén pluton. Argentina, Actas XVIII Congreso Geológico Argentino. S12 Tectónica Andina, Neuquén, p. 2.

Cunningham, W.D., 1994. Uplifted ophiolitic rocks on Isla Gordon, southernmost Chile: implications for the closure history of the Rocas Verdes marginal basin and the tectonic evolution of the Beagle Channel region. Journal of South American Earth Sciences 7, 135-147.

Cunningham, W.D., 1995. Orogenesis at the southern tip of the Americas: the structural evolution of the Cordillera Darwin metamorphic complex, southernmost 
1025

1026

1027

1028

1029

1030

1031

1032

1033

1034

1035

1036

1037

1038

1039

1040

1041

1042

1043

1044

1045

1046

1047

1048

Dalziel, I.W.D., 1981. Back-arc extension in the southern Andes: a review and critical reappraisal. Philosophical Transactions of the Royal Society of London. Series A, Mathematical and Physical Sciences 300, 319-335.

Dalziel, I.W.D., 1986. Collision and Cordilleran orogenesis: an Andean perspective. Geological Society, London, Special Publications 19, 389-404.

Dalziel, I.W.D., de Wit, M.J., Palmer, K.F., 1974. Fossil marginal basin in the southern Andes. Nature 250, 291-294.

Dalziel, I.W.D., Palmer, K.F., 1979. Progressive deformation and orogenic uplift at the southern extremity of the Andes. Geological Society of America Bulletin 90, 259280.

Galeazzi, J.S., 1998. Structural and stratigraphic evolution of the western Malvinas Basin, Argentina. AAPG Bulletin 82, 596-636.

Ghiglione, M.C., 2002. Diques clásticos asociados a deformación transcurrente en depósitos sinorogénicos del Mioceno inferior de la Cuenca Austral. Revista de la Asociación Geológica Argentina 57, 103-118.

Ghiglione, M.C., Quinteros, J., Yagupsky, D., Bonillo-Martínez, P., Hlebszevtich, J., Ramos, V.A., Vergani, G., Figueroa, D., Quesada, S., Zapata, T., 2010. Structure and tectonic history of the foreland basins of southernmost South America. Journal of South American Earth Sciences 29, 262-277.

Gombosi, D.J., Barbeau Jr, D.L., Garver, J.I., 2009. New thermochronometric constraints on the rapid Palaeogene exhumation of the Cordillera Darwin complex and related thrust sheets in the Fuegian Andes. Terra Nova 21, 507-515.

González Guillot, M., 2016. Magmatic Evolution of the Southernmost Andes and Its Relation with Subduction Processes, In: C. Ghiglione, M. (Ed.), Geodynamic 
1049 Evolution of the Southernmost Andes: Connections with the Scotia Arc. Springer

1050 International Publishing, Cham, pp. 37-74.

1051 González Guillot, M., 2017. Evidencias de emplazamiento simultáneo de facies básicas

1052 y ácidas del magmatismo Jurásico de los Andes Fueguinos, In: Ibáñez, L.M., Grosse,

1053 P., Báez, M.A. (Eds.), Actas XX Congreso Geológico Argentino, Sesión Técnica 4

1054 Petrología y geoquímica de rocas ígneas. Asociación Geológica Argentina, San

1055 Miguel de Tucumán, pp. 42-47.

1056 González Guillot, M., Escayola, M., Acevedo, R., 2011. Calc-alkaline rear-arc

1057 magmatism in the Fuegian Andes: Implications for the mid-cretaceous

1058

tectonomagmatic evolution of southernmost South America. Journal of South

1059 American Earth Sciences 31, 1-16.

1060 González Guillot, M., Prezzi, C., Acevedo, R.D., Escayola, M., 2012. A comparative study

1061 of two rear-arc plutons and implications for the Fuegian Andes tectonic evolution:

1062 Mount Kranck Pluton and Jeu-Jepén Monzonite, Argentina. Journal of South

1063 American Earth Sciences 38, 71-88.

1064 González Guillot, M., Escayola, M., Acevedo, R., Pimentel, M., Seraphim, G., Proenza, J.,

1065 Schalamuk, I., 2009. The Plutón Diorítico Moat: Mildly alkaline monzonitic

1066 magmatism in the Fuegian Andes of Argentina. Journal of South American Earth

1067 Sciences 28, 345-359.

1068 González Guillot, M., Ghiglione, M., Escayola, M., Martins Pimentel, M., Mortensen, J.,

1069 Acevedo, R., 2018. Ushuaia pluton: Magma diversification, emplacement and

1070 relation with regional tectonics in the southernmost Andes. Journal of South

1071 American Earth Sciences 88, 497-519. 
1072

1073

1074

1075

1076

1077

1078

1079

1080

1081

1082

1083

1084

1085

1086

1087

1088

1089

1090

1091

1092

1093

1094

1095

González Guillot, M., Urraza, I., Acevedo, R.D., Escayola, M., 2016. Magmatismo básico jurásico-cretácico en los Andes Fueguinos y su relación con la Cuenca Marginal Rocas Verdes. Revista de la Asociación Geológica Argentina 73, 1-22.

Hanson, B., Wilson, T., 1991. Submarine rhyolitic volcanism in a Jurassic proto-marginal basin, southern Andes, Chile and Argentina, In: Harmon, R., Rapela, C. (Eds.), Andean magmatism and its tectonic setting, Geologic Society of America Special Paper. Geological Society of America, Boulder, pp. 13-27.

Hervé, F., Calderón, M., Fanning, C.M., Kraus, S., Pankhurst, R.J., 2010a. SHRIMP chronology of the Magallanes Basin basement, Tierra del Fuego: Cambrian plutonism and Permian high-grade metamorphism. Andean Geology 37, 253-275.

Hervé, F., Fanning, C.M., Pankhurst, R.J., Mpodozis, C., Klepeis, K., Calderón, M., Thomson, S.N., 2010b. Detrital zircon SHRIMP U-Pb age study of the Cordillera Darwin Metamorphic Complex of Tierra del Fuego: sedimentary sources and implications for the evolution of the Pacific margin of Gondwana. Journal of the Geological Society $167,555-568$.

Hervé, F., Nelson, E., Kawashita, K., Suárez, M., 1981. New isotopic ages and the timing of orogenic events in the Cordillera Darwin, southernmost Chilean Andes. Earth and Planetary Science Letters 55, 257-265.

Klepeis, K.A., 1994. Relationship between uplift of the metamorphic core of the southernmost Andes and shortening in the Magallanes foreland fold and thrust belt, Tierra del Fuego, Chile. Tectonics 13, 882-904.

Hervé, M., Suárez, M., Puig, A., 1984. The Patagonian Batholith S of Tierra del Fuego, Chile: timing and tectonic implications. Journal of the Geological Society $141,909-$ 917. 
1096

1097

1098

1099

1100

1101

1102

1103

1104

1105

1106

1107

1108

1109

1110

1111

1112

1113

1114

1115

1116

1117

Klepeis, K.A., Betka, P., Clarke, G., Fanning, M., Hervé, F., Rojas, L., Mpodozis, C., Thomson, S., 2010. Continental underthrusting and obduction during the Cretaceous closure of the Rocas Verdes rift basin, Cordillera Darwin, Patagonian Andes. Tectonics 29, TC3014.

Kley, J., Monaldi, C.R., Salfity, J.A., 1999. Along-strike segmentation of the Andean foreland: causes and consequences. Tectonophysics 301, 75-94.

Kohn, M.J., Spear, F.S., Dalziel, I.W.D., 1993. Metamorphic P-T Paths from Cordillera Darwin, a Core Complex in Tierra del Fuego, Chile. Journal of Petrology 34, 519-542.

Kohn, M.J., Spear, F.S., Harrison, T.M., Dalziel, I.W.D., 1995. 40Ar/39Ar geochronology and P-T-t paths from the Cordillera Darwin metamorphic complex, Tierra del Fuego, Chile. Journal of Metamorphic Geology 13, 251-270.

Kraemer, P.E., 2003. Orogenic shortening and the origin of the Patagonian orocline ( $56^{\circ}$ S.Lat). Journal of South American Earth Sciences 15, 731-748.

Kranck, E.H., 1932. Geological investigations in the Cordillera of Tierra del Fuego. Acta Geographica Societas Geographica Fenniae 4, 1-231.

Maestro, A., Ruano, P., Torres Carbonell, P., Bohoyo, F., Galindo-Zaldívar, J., Pedrera, A., Ruiz-Constán, A., González-Castillo, L., Ibarra, P., López-Martínez, J., 2019. Stress field evolution of the southernmost Andean Cordillera from paleostress analysis (Argentine Tierra del Fuego). Tectonics 38, 7-25.

Maloney, K.T., Clarke, G.L., Klepeis, K.A., Fanning, C.M., Wang, W., 2011. Crustal growth during back-arc closure: Cretaceous exhumation history of Cordillera Darwin, southern Patagonia. Journal of Metamorphic Geology 29, 649-672. 
1118 Malumián, N., 2002. El Terciario marino. Sus relaciones con el eustatismo., In: Haller,

1119 M.J. (Ed.), Geología y Recursos Naturales de Santa Cruz. Relatorio XV Congreso

1120 Geológico Argentino. Asociación Geológica Argentina, Buenos Aires, pp. 237-244.

1121 Malumián, N., Hromic, T., Náñez, C., 2013. El Paleógeno de la Cuenca Magallanes:

1122 bioestratigrafía y discontinuidades. Anales Instituto Patagonia (Chile) 41, 29-52.

1123 Malumián, N., Olivero, E.B., 2006. El Grupo Cabo Domingo, Tierra del Fuego:

1124 bioestratigrafía, paleoambientes y acontecimientos del Eoceno-Mioceno marino.

1125 Revista de la Asociación Geológica Argentina 61, 139-160.

1126 Martinioni, D.R., Linares, E., Acevedo, R.D., 1999. Significado de la edad isotópica de

1127 diques básicos intruidos en la Formación Beauvoir (Cretácico Temprano), Tierra del

1128 Fuego. Revista de la Asociación Geológica Argentina 54, 88-91.

1129 Martinioni, D.R., Olivero, E.B., Medina, F.A., Palamarczuk, S.C., 2013. Cretaceous

1130 stratigraphy of Sierra de Beauvoir, Fuegian Andes (Argentina). Revista de la

1131 Asociación Geológica Argentina 70, 70-95.

1132 McAtamney, J., Klepeis, K., Mehrtens, C., Thomson, S., Betka, P., Rojas, L., Snyder, S.,

1133 2011. Along-strike variability of back-arc basin collapse and the initiation of

1134 sedimentation in the Magallanes foreland basin, southernmost Andes $\left(53-54.5^{\circ} \mathrm{S}\right)$.

1135 Tectonics 30, TC5001.

1136 Mukasa, S.B., Dalziel, I.W.D., 1996. Southernmost Andes and South Georgia Island,

1137 North Scotia Ridge: Zircon U-Pb and muscovite 40Ar39Ar age constraints on

1138 tectonic evolution of Southwestern Gondwanaland. Journal of South American

$1139 \quad$ Earth Sciences 9, 349-365. 
1140 Nelson, E.P., 1982. Post-tectonic uplift of the Cordillera Darwin orogenic core complex:

1141 evidence from fission track geochronology and closing temperature-time

1142 relationships. Journal of the Geological Society 139, 755-761.

1143 Nelson, E.P., Dalziel, I.W.D., Milnes, A.G., 1980. Structural geology of the Cordillera

1144 Darwin - Collisional-style orogenesis in the southernmost Chilean Andes. Eclogae 1145 Geologicae Helvetiae 73, 727-751.

1146 Olivero, E.B., Martinioni, D.R., 1996a. Sedimentología de las Formaciones Lemaire y 1147 Yahgan (Jurásico-Cretácico) en Tierra del Fuego. Actas XIII Congreso Geológico 1148 Argentino y III Congreso de Exploración de Hidrocarburos 2, 45-59.

1149 Olivero, E.B., Martinioni, D.R., 1996b. Late Albian inoceramid bivalves from the Andes 1150 of Tierra del Fuego: Age implications for the closure of the Cretaceous Marginal 1151 Basin. Journal of Paleontology 70, 272-274.

1152 Olivero, E.B., Acevedo, R.D., Martinioni, D.R., 1997. Geología del Mesozoico de bahía 1153 Ensenada, Tierra del Fuego. Revista de la Asociación Geológica Argentina 52, 169$1154 \quad 179$

1155 Olivero, E.B., Barreda, V., Marenssi, S.A., Santillana, S.N., Martinioni, D.R., 1998.

1156 Estratigrafía, sedimentología y palinología de la Formación Sloggett (Paleógeno 1157 continental), Tierra del Fuego. Revista de la Asociación Geológica Argentina 53, 504$1158 \quad 516$.

1159 Olivero, E.B., Malumián, N., 2008. Mesozoic-Cenozoic stratigraphy of the Fuegian $1160 \quad$ Andes, Argentina. Geologica Acta 6, 5-18.

1161 Olivero, E.B., Malumián, N., Palamarczuk, S., Scasso, R.A., 2002. El Cretácico superior1162 Paleógeno del área del Río Bueno, costa atlántica de la Isla Grande de Tierra del 1163 Fuego. Revista de la Asociación Geológica Argentina 57, 199-218. 
1164 Olivero, E.B., Malumián, N., Palamarczuk, S., 2003. Estratigrafía del Cretácico Superior-

1165 Paleoceno del área de Bahía Thetis, Andes fueguinos, Argentina: acontecimientos

1166 tectónicos y paleobiológicos. Revista Geológica de Chile 30, 245-263.

1167 Olivero, E.B., Medina, F.A., López Cabrera, M.I., 2009. The stratigraphy of cretaceous

1168 mudstones in the eastern Fuegian Andes: new data from body and trace fossils.

1169 Revista de la Asociación Geológica Argentina 64, 60-69.

1170 Palotti, P., Menichetti, M., Cerredo, M.E., Tassone, A., 2012. A new U-Pb zircon age

1171 determination for the Lemaire Formation of Fuegian Andes, Tierra del Fuego,

1172 Argentina. Rendiconti Online Della Società Geologica Italiana 22, 170-173.

1173 Pankhurst, R.J., Riley, T.R., Fanning, C.M., Kelley, S.P., 2000. Episodic Silicic Volcanism

1174 in Patagonia and the Antarctic Peninsula: Chronology of Magmatism Associated

1175 with the Break-up of Gondwana. Journal of Petrology 41, 605-625.

1176 Ponce, J.J., Olivero, E.B., Martinioni, D.R., 2008. Upper Oligocene-Miocene clinoforms

1177 of the foreland Austral Basin of Tierra del Fuego, Argentina: Stratigraphy,

1178 depositional sequences and architecture of the foredeep deposits. Journal of South

1179 American Earth Sciences 26, 36-54.

1180 Rojas, L., Mpodozis, C., 2006. Geología estructural de la faja plegada y corrida de Tierra

1181 del Fuego, Andes Patagónicos Chilenos, XI Congreso Geológico Chileno,

$1182 \quad$ Antofagasta, Chile, pp. 325-328.

1183 Sánchez, A., Pavlishina, P., Godoy, E., Hervé, F., Fanning, C.M., 2010. On the presence 1184 of Upper Paleocene rocks in the foreland succession at Cabo Nariz, Tierra del Fuego, 1185 Chile: geology and new palynological and U-Pb data. Andean Geology 37, 413-432. 1186 SERNAGEOMIN, 2003. Mapa Geológico de Chile. Scale 1:1,000,000. Servicio Nacional 1187 de Geología y Minería, Santiago. 
1188 Stern, C.R., de Wit, M.J., 2003. Rocas Verdes ophiolites, southernmost South America:

1189 remnants of progressive stages of development of oceanic-type crust in a

1190 continental margin back-arc basin. Geological Society, London, Special Publications $1191 \quad 218,665-683$.

1192 Storey, B.C., 1983. The geology of South Georgia: V. Drygalski Fjord Complex, British Antarctic Survey Reports 107. British Antarctic Survey, Cambridge.

Suárez, M., Pettigrew, T.H., 1976. An Upper Mesozoic island-arc-back-arc system in the southern Andes and South Georgia. Geological Magazine 113, 305-328.

Tanner, P.W.G., Macdonald, D.I.M., 1982. Models for the deposition and simple shear deformation of a turbidite sequence in the South Georgia portion of the southern Andes back-arc basin. Journal of the Geological Society 139, 739-754.

Torres Carbonell, P.J., Dimieri, L.V., Olivero, E.B., 2011. Progressive deformation of a Coulomb thrust wedge: the eastern Fuegian Andes Thrust-Fold Belt, In: Poblet, J., Lisle, R. (Eds.), Kinematic Evolution and Structural Styles of Fold-and-Thrust Belts, Geological Society, London, Special Publications. The Geological Society, Bath, pp. 123-147.

Torres Carbonell, P.J., Dimieri, L.V., 2013. Cenozoic contractional tectonics in the Fuegian Andes, southernmost South America: a model for the transference of orogenic shortening to the foreland. Geologica Acta 11, 359-370. depositional systems in a fossil, marine foreland basin: Example from the SE Austral Basin, Tierra del Fuego, Argentina. Marine and Petroleum Geology 104, 40-60. 
1210 Torres Carbonell, P.J., Dimieri, L.V., Olivero, E.B., 2013a. Evaluation of strain and

1211 structural style variations along the strike of the Fuegian thrust-fold belt front, $1212 \quad$ Argentina. Andean Geology 40, 438-457.

1213 Torres Carbonell, P.J., Dimieri, L.V., Martinioni, D.R., 2013b. Early foreland deformation 1214 of the Fuegian Andes (Argentina): Constraints from the strain analysis of Upper Cretaceous-Danian sedimentary rocks. Journal of Structural Geology 48, 14-32.

Torres Carbonell, P.J., Dimieri, L.V., Olivero, E.B., Bohoyo, F., Galindo-Zaldívar, J., 2014. Structure and tectonic evolution of the Fuegian Andes (southernmost South Change 123, Part B, 174-188.

Torres Carbonell, P.J., Rodríguez Arias, L., Atencio, M.R., 2017a. Geometry and kinematics of the Fuegian thrust-fold belt, southernmost Andes. Tectonics 36, 3350.

Torres Carbonell, P.J., Cao, S.J., Dimieri, L.V., 2017b. Spatial and temporal characterization of progressive deformation during orogenic growth: Example from the Fuegian Andes, southern Argentina. Journal of Structural Geology 99, 1-19.

Torres Carbonell, P., González Guillot, M., Cao, S., Dimieri, L., 2017c. Relación temporal y estructural entre intrusivos del arco magmático y la faja corrida y plegada Fueguina en la sierra Beauvoir, In: Ibáñez, L.M., Grosse, P., Báez, M.A. (Eds.), Actas XX Congreso Geológico Argentino, Simposio 12 Tectónica de los Andes argentinochilenos. Asociación Geológica Argentina, San Miguel de Tucumán, pp. 259-264.

Torres Carbonell, P.J., Maestro, A., Ruano, P., Galindo-Zaldívar, J. 2019. Superposed deformation in the Península Mitre recess (Fuegian thrust-fold belt, Southern 
Argentina), and implications for orogenic curve kinematics. Journal of Structural

Winn, J.R.D., 1978. Upper Mesozoic flysch of Tierra del Fuego and South Georgia

Zanella, A., Cobbold, P.R., Rojas, L., 2014. Beef veins and thrust detachments in Early maturation. Marine and Petroleum Geology 55, 250-261.

\section{Figure captions}

Figure 1: a. Geologic map of southernmost Patagonia and Tierra del Fuego with regional structural elements discussed in this work. S: Sarmiento Complex, CA: Capitán Aracena Complex. T: Tortuga Complex, LF: Lago Fagnano, CB: Canal Beagle. Based on

works cited in the text. b. Cartoon showing closure of the back-arc basin and development of the Fuegian Andes during two main tectonic events, involving collision and later thrust-fold belt (TFB) expansion. Known intrusive pulses during both events are schematically depicted (modified from Torres Carbonell et al., 2014).

Figure 2: Stratigraphic framework of the Fuegian thrust-fold belt north of Canal Beagle, with nomenclature used in Argentina and Chile. For a more complete regional correlation see Torres Carbonell and Olivero (2019). References are 1: Biddle et al. (1986), Cañón (2000), Sánchez et al. (2010), McAtamney et al. (2011), Malumián et al. 
1256 (2013), 2: Malumián and Olivero (2006), Olivero and Malumián (2008), Martinioni et al.

1257 (2013), Cao et al. (2018), 3: Klepeis et al. (2010), McAtamney et al. (2011), Cerredo et

1258 al. (2011), González Guillot et al. (2018). An idealized lithologic column is shown,

1259

1260

1261

1262

1263

1264

1265

1266

1267

1268

1269

1270

1271

1272

1273

1274

1275

1276

1277

1278 although lateral facies variations exist. Minimum thicknesses reported for reference are from the thicker composite sections and in some cases highly variable.

Figure 3: Geologic map of the Fuegian thrust-fold belt with main structural features and stratigraphic units mentioned in the text. See location in Fig. 1a, and text for details of stratigraphic units. Compiled from Klepeis (1994), SERNAGEOMIN (2003), Olivero and Malumián (2008), Hervé et al. (2010b), Klepeis et al. (2010), González Guillot (2016), Cao (2019), Torres Carbonell and Olivero (2019), and authors' data. Cross-sections $x-y$ and $y-z$ indicate location of Fig. 12a. Pt: Parry thrust, MM: Montes Martial, UP: Ushuaia pluton, UPA: Ushuaia Peninsula Andesites, JP: Jeu-Jepén pluton, MP: Moat pluton, BP: Bahía Pía, BT: Bahía Thetis.

Figure 4: Time constraints for the deformations recorded in the Fuegian thrust-fold belt, north of Canal Beagle, as addressed in this work. Modified from Torres Carbonell and Dimieri (2013). Bold bars indicate $2 \sigma$ uncertainties. UPA: Ushuaia Peninsula Andesites, FPM: Fuegian Potassic Magmatism. References: 1: Nelson (1982), 2: Kohn et al. (1995), 3: Gombosi et al. (2009), 4: Klepeis et al. (2010), 5: Olivero and Martinioni (1996b), 6: Nelson et al. (1980), 7: Olivero et al. (2003), 8: McAtamney et al. (2011), 9: Torres Carbonell et al. (2011), 10: Maloney et al. (2011), 11: Cerredo et al. (2011), 12: Barbeau et al. (2009b), 13: González Guillot et al. (2018), 14: Torres Carbonell et al. 
1279 (2017b), 15: Olivero et al. (1998), 16: this work. Red and black double arrows labeled "D" are discussed in sections 6 and 7.

1281

Figure 5: a-d. Outcrop photographs of the Ushuaia Peninsula Andesites (UPA) and host rock (Yahgan Formation, YG). Notice the lack of intense deformation in pictures a (person for scale) and $\mathbf{b}$, from the main body of the intrusion. In picture $\mathbf{c}$ the Yahgan Formation shows slight folding and cleavage away from the main body of the intrusion (scale is $6 \mathrm{~cm}$ long). Picture $\mathbf{d}$ shows a dike and its host rock affected by pressuresolution cleavage (parallel to compass), farther away from the main intrusion. e-f. Photomicrographs of cleavage in the dike of picture $\mathbf{d}$, plane-polarized light. Note horizontal pressure-solution seams with wriggly morphology defined by opaque insoluble residue. PI: plagioclase, $\mathrm{Hbl}$ : hornblende (chloritized), Aln: allanite. g. Hornfels from the Jeu-Jepén pluton (Beauvoir Formation) with scarce pressure-solution seams (from upper-right to lower-left) reflecting the prior cleavage, which is obliterated by recrystallization of the plagioclase + quartz $(Q z)$ groundmass, dissemination of insoluble residue inherited from the pressure-solution seams, and growth of biotite $(\mathrm{Bt})$ parallel to the preexisting cleavage planes.

Figure 6: a. Geologic map of the Cañadón Bianchi area (location in Fig. 3). Equal area, lower hemisphere projection shows orientation of crenulation folds in the area. Brittleductile shear zones (BDZS) are numbered for reference to picture $\mathbf{b}$. Location of photographs c-j is shown. b. Panoramic photograph with depiction of major structures as shown in a. Acronyms are for stratigraphic units in the map. c-d. Outcrop (backpack for scale) and close-up view of cataclastic fabrics in thrust zones. e. S-C type fabric 
1303

1304

1305

1306

1307

1308

1309

1310

1311

1312

1313

1314

1315

1316

1317

1318

1319

1320

1321

1322

1323

showing top-to-north component of movement. f. Cataclasite block revealing faulted folds (horizontal trace) affecting an older transposition foliation (alternating lighter and darker bands). Encircled 23-mm coin for scale. g. Photomicrograph of a cataclasite from a thrust zone affecting older quartz-mica schist, cross-polarized light. $\mathbf{h}$. Faulted folds in the detachment at the base of the Yahgan Formation. Notice the style of folding with thickened hinge and thinned limbs in the lower left of the photograph. i.

Crenulation of a previous foliation in the upper flat of the BDSZ 1. Scale is $6 \mathrm{~cm}$ long. $\mathbf{j}$. S-C type fabric showing northeastward component of displacement in the detachment zone. $k$. Cross-section (located in a) showing the first-order synform affecting the detachment.

Figure 7: a. Panoramic photograph of the structure at Arroyo Velazquito. The detachment near the base of the Beauvoir Formation is folded by a large antiform. Towards the north, the beds dip northwards with progressively shallower angles (values given in dip direction/dip). b-d. Details of brittle-ductile fault fabrics in the detachment zone (located in a), superposed on older foliations and folds. In b, s-c type fabrics show a component of northward displacement (notice that north points to the lower left). 6-cm scale highlighted. Brecciated folds (arrows) and cataclastic fabric are shown in $\mathbf{c}$ and $\mathbf{d}$.

Figure 8: Schematic description and examples of $D 1_{C B}$ structures (a) and $D 2_{C B}-D 1_{F B}$ structures (b), further explained in section 6. S0: bedding, J: Jurassic and older, $\mathrm{Kl}$ : Lower Cretaceous, Ku: Upper Cretaceous. Cross-sections are idealized and not to scale. 
1327 Figure 9: Map of the Kranck pluton and Cerro Rodríguez dikes, with distribution of

1328

1329

1330

1331

1332

1333

deformed and undeformed dike sets mentioned in the text. Location of dated samples is shown. Equal area projection shows poles to cleavage in the Beauvoir Formation (black) and the deformed dike set (red), with n number of measurements.

Figure 10: a-c. Outcrop examples of deformed Cerro Rodríguez dikes. Notice the good development of pressure-solution cleavages parallel to the cleavage in the host rock. d-f. Photomicrographs (plane-polarized light) showing the stylolitic or wriggly pressuresolution seams defining the spaced cleavage. Phenocrysts are very altered pseudomorphs of plagioclase, clinopyroxene or hornblende. In picture $\mathbf{f}$ a detail of bended biotite is shown, with the axial planes of the microfolds subparallel to cleavage (subvertical).

Figure 11: a. Wetherill concordia plot for zircon age determination from a quartz monzonite of the Kranck pluton (sample BR47). b-c. Hornblende (Hbl) Ar/Ar plateau ages for (b) sample BR29 (hornblendite, Kranck pluton) and (c) sample 104 (Hbl lamprophyre, Cerro Rodríguez dikes). The weighted mean age was integrated over the steps between the arrows.

Figure 12: a. Balanced cross-section of the Fuegian thrust-fold belt. The cross-section was constructed along an assumed continuous trace x-z (see location in Fig. 3), considering that the segment $y-z$ was located behind $x-y$ before the $c .50 \mathrm{~km}$ leftlateral strike offset produced by the Neogene Fagnano transform fault system (cf. Torres Carbonell et al., 2014). AMTS: Apen-Malvinera thrust system. b. Sequential 
1351 forward modelling of the interpreted structures shown in a, using Move-on-Fault

1352 algorithms in MOVE software. Eroded spaces are left blank for simplicity. 


\section{Journal Pre-proof}

Arc-continent collision related orogenesis caused high-grade to mild deformation

New structural data and $\mathrm{Ar} / \mathrm{Ar}-\mathrm{U} / \mathrm{Pb}$ ages of intrusives is reported

First deformation in the central belt of Argentina occurred from 84 to $74 \mathrm{Ma}$

Subsequent deformation involved a brittle-ductile to brittle thrust system

These thrusts join a common upper detachment transferring shortening to foreland 


\section{Declaration of interests}

$\bigotimes$ The authors declare that they have no known competing financial interests or personal relationships that could have appeared to influence the work reported in this paper.

$\square$ The authors declare the following financial interests/personal relationships which may be considered as potential competing interests: 